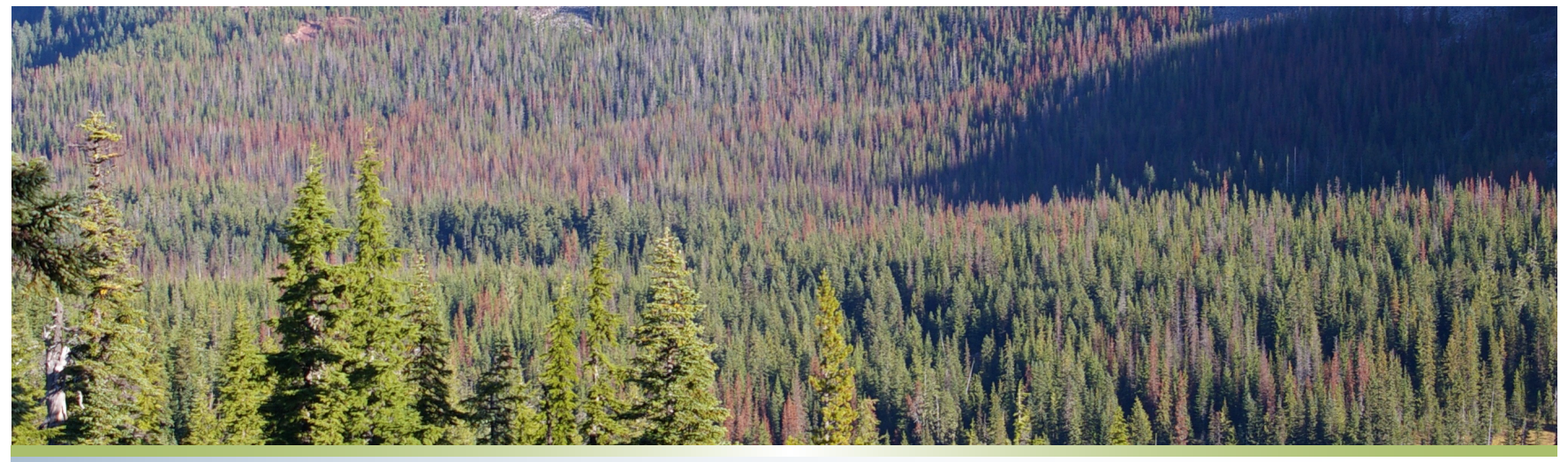

7: Forests

\title{
Forest Ecosystems, Disturbances, and Climatic Change in Washington State, USA
}

\author{
Jeremy S. Littell', Elaine E. Oneil', Donald McKenzie',3, Jeffrey A. Hicke4, James A. Lutz', Robert A. Norheim¹,3, \\ Marketa M. Elsner'
}

\section{Abstract}

$\mathrm{C}$

limatic change is likely to affect Pacific Northwest (PNW) forests in several important ways. In this paper, we address the role of climate in four forest ecosystem processes and project the effects of future climatic change on these processes. First, we analyze how climate affects Douglas-fir growth across the region to understand potential changes in future growth. In areas where Douglas-fir is not water-limited, future growth will continue to vary with interannual climate variability, but in places where Douglas-fir is water-limited, growth is likely to decline due to projected increase in summer potential evapotranspiration. Second, we use existing analyses of climatic controls on future potential tree species ranges to highlight areas where species turnover may be greatest. By the mid $21^{\text {st }}$ century, some areas of the interior Columbia Basin and eastern Cascades are likely to have climates poorly suited to pine species that are susceptible to mountain pine beetle, and if these pines are climatically stressed, they may be more vulnerable to pine beetle attack. Climatic suitability for Douglas-fir is also likely to change, with substantial decreases in climatically suitable area in the Puget Trough and the Okanogan Highlands. Third, using regression approaches, we examine the relationships between climate and the area burned by fire in the PNW and in eight Washington ecosystems and project future area burned in response to changing climate. Area burned is significantly related to both temperature and precipitation in summer, but more physiologically relevant variables, such as water balance deficit, perform as well or better in models. Regional area burned is likely to double or even triple by the end of the 2040s, although Washington ecosystems have different sensitivities to climate and thus different responses to climatic change. Fourth, we evaluate the influence of climatic change on mountain pine beetle (MPB) outbreaks by quantifying both host-tree vulnerability and pine beetle adaptive seasonality. Host-tree vulnerability is closely related to vapor pressure deficit (VPD), and future projections support the hypothesis that summer VPD will increase over a significant portion of the range of host tree species. Due to the increased host

\footnotetext{
1 JISAO Climate Impacts Group, University of Washington, Seattle, Washington

2 Rural Technology Initiative, College of Forest Resources, University of Washington, Seattle, Washington

${ }^{3}$ USDA Forest Service Pacific Northwest Research Station, Seattle, Washington

${ }^{4}$ Department of Geography, University of Idaho, Moscow, Idaho

${ }^{5}$ College of Forest Resources, University of Washington, Seattle, Washington
} 
vulnerability, MPB populations are expected to become more viable at higher elevations leading to increased incidence of MPB outbreaks. The increased rates of disturbance by fire and mountain pine beetle are likely to be more significant agents of changes in forest structure and composition in the 21 st century than species turnover or declines in productivity. This suggests that understanding future disturbance regimes is critical for successful adaptation to climate change.

\section{Introduction}

Global climate change is expected to affect Earth's ecosystems in many ways (IPCC Working Group II, 2007). Terrestrial ecosystems may experience widespread mortality of vegetation from the direct effects of changes in temperature and precipitation (Breshears et al. 2005, Lutz and Halpern, 2006, van Mantgem and Stephenson, 2007; van Mantgem et al. 2009) and from increased extent, intensity, and frequency of disturbance (McKenzie et al., 2004; Gedalof et al., 2005, Littell, 2006, Littell et al., in press). New ecosystem types, comprising heretofore rare or non-existent combinations of species, may succeed those no longer adapted to new climates, in turn changing landscape structure and spatial pattern across a range of scales (Davis 1986). Anticipating these changes is challenging, but necessary to support long-term planning, natural resources management, and maintenance of the myriad services that ecosystems provide.

In the Pacific Northwest (PNW) region of U.S. North America (here defined as Washington, Oregon, Idaho, and western Montana), forests, both on public and private lands, are a key natural resource. In Washington State alone, forests cover 8,926,490 ha (Figure 1), 52\% of the total area of the state. Approximately 56\% ( 5 million ha) of this forested land is publicly owned, administered by federal (U.S. Departments of Agriculture and Interior) and state (WA Department of Natural Resources) agencies. The remainder is managed by tribal, private, and corporate landowners. Legal mandates and owner objectives for these lands vary, but all may be affected by a changing climate.

Conifer species dominate forest ecosystems within Washington State, with hardwood species abundant only in riparian areas that experience frequent flooding or other heavily disturbed areas such as avalanche chutes or recently logged sites. Forest composition varies with both elevation and position on a west-east (maritime-continental) gradient across the state. At a finer scale, orographic effects on species composition are apparent on the leeward versus windward sides of both the Olympic Mountains and the Cascade Range, where complex topography produces steep gradients in the biophysical environment across relatively short distances (Williams and Lillybridge, 1983; Franklin and Dyrness, 1988; Henderson et al., 1989, 1992; Williams et al. 1990; Lillybridge et al. 1995).

Research from many ecosystems around the world at many scales has documented climatic controls on vegetation (Davis and Botkin 1985, Overpeck et al. 1990, Guisan and Zimmerman 2000). Climatic limiting factors operate mechanistically through the interface between organisms and their environment. Plant performance is compromised when one or more resources (e.g., light, thermal energy, water, nutrients) are limiting. At 


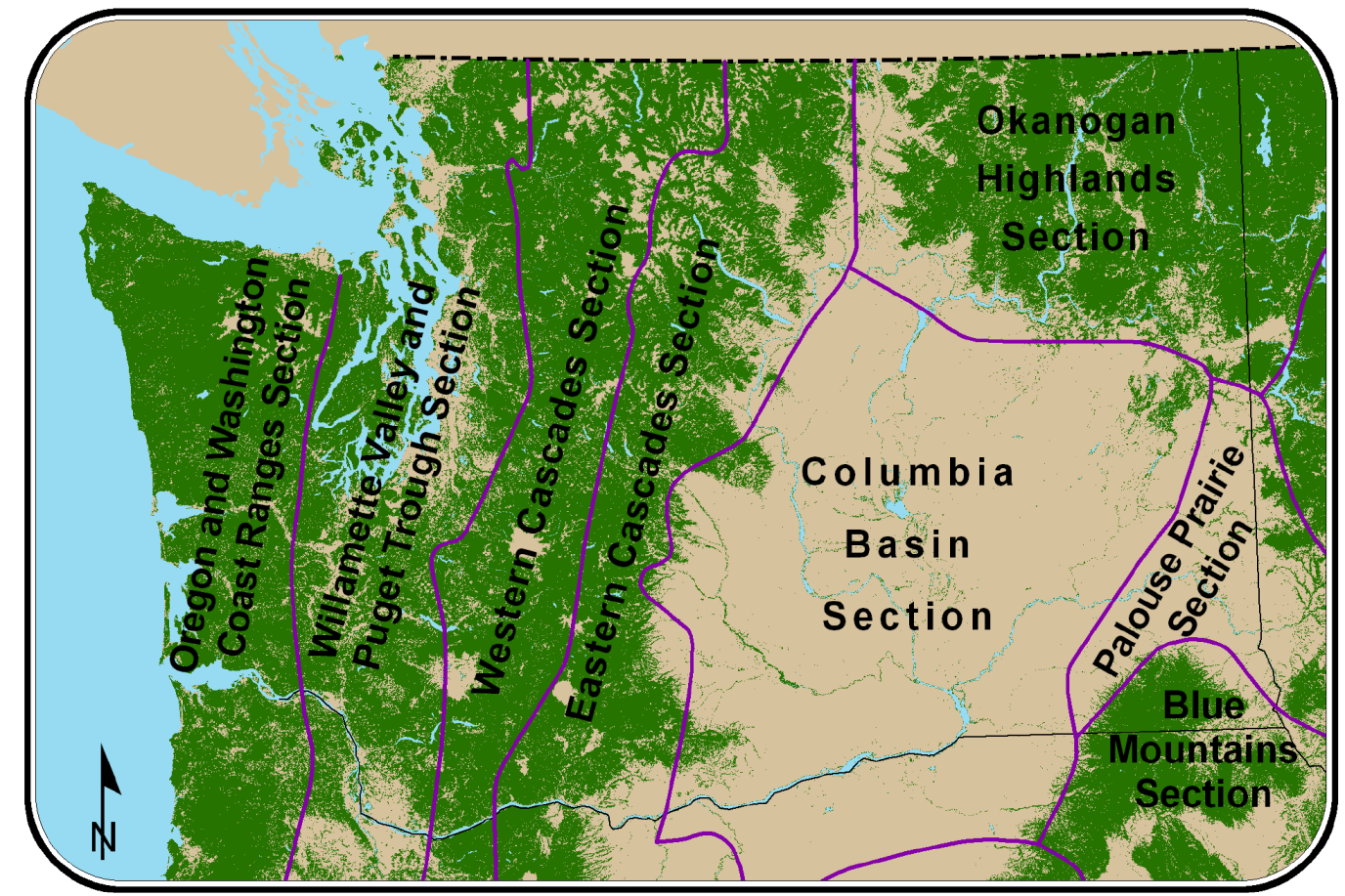

Figure 1. Forested areas of Washington State, and Bailey's ecosections used for sub-regional fire modeling. broad scales, forests of western North America can be partitioned into two climatically mediated classes of limitation: energy-limited versus waterlimited domains (Milne et al., 2002, McKenzie et al., 2003, Running et al., 2004, Littell and Peterson, 2005, Littell et al., 2008). Energy-limiting factors are chiefly light (e.g., productive forests where competition reduces light to most individuals or climates where cloud cover limits light) and temperature (e.g., high-latitude or high-elevation forests). Tree growth in energy-limited ecosystems appears to be responding positively to warming temperatures over the past 100 years (McKenzie et al., 2001).

In contrast, productivity in water-limited systems is expected to decline with warming temperatures, as increasing water balance deficit (the condition in which potential summer atmospheric and plant demands exceed available soil moisture) constrains photosynthesis across more of the West (Figure 2). There is evidence to support the hypothesis that $\mathrm{CO}_{2}$ fertilization significantly increases water-use efficiency in plants (Boisvenue and Running, 2007) enough to partially offset future water demands (e.g., in model studies, Neilson et al., 2005, Lenihan et al., 2008), but conclusive results have not been forthcoming, and the overall expected change is decreasing water availability for plants in summer (Figure 2). Littell et al., (2008) found that most montane Douglas-fir (Pseudotsuga menziesii) forests across the northwestern United States appear to be currently water-limited; under all but the wettest climate projections water limitations will increase in both area and magnitude because increased potential evapotranspiration will exceed precipitation supply by more than it does currently.

Cool season surplus (runoff; precipitation and snow melt less plant use and soil water recharge) and summer water deficit can increase simultaneously in a warmer climate (Figure 2). In the base case (1980 - 1999 climate), precipitation is low during summer months, and winter temperatures are 


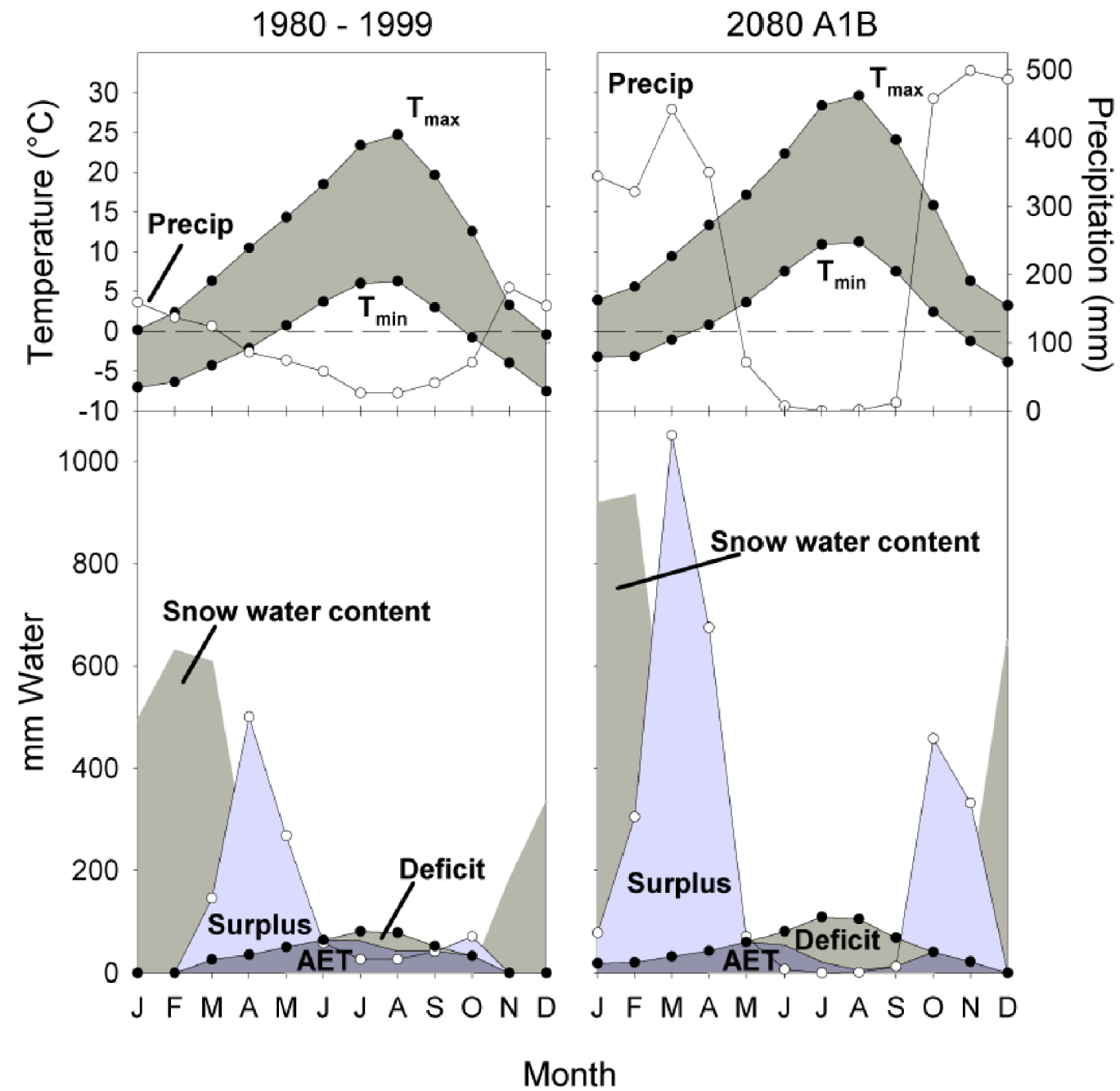

Figure 2. Physical (top) and biophysical (bottom) aspects of present and modeled future climate for a study plot in the Umatilla National Forest, SE Washington, slope 34 degrees, southwest aspect. below freezing. Water supply (rain plus snowmelt) is less than evaporative demand (PET) from June through September. In the 2080 A1B composite scenario, summer precipitation is almost zero, and winter temperatures are no longer below freezing. Water supply is less than evaporative demand from May through October, resulting in a longer seasonal deficit. This is generally consistent with the findings of Elsner et al. (2009, this report), in which projected changes in winter temperature and precipitation result in decreased snowpack, summer temperatures increase, and summer soil moisture declines over much of the PNW.

Limiting factors can of course shift within a species range (Peterson and Peterson, 2001), or between seasons, as water demands abate and energy needs increase (Stephenson, 1990, 1998; Lutz, 2008). For example, in high-elevation or high-latitude arid forests (e.g., eastern slopes of the Sierra Nevada, Rocky Mountain Front Range, interior boreal spruce), short growing seasons limit energy inputs, but drought stress still occurs in summer. Similarly, climatic variability can alter the temperature and or precipitation such that limiting factors are exacerbated or mitigated for years or decades at a time; limiting factors can therefore also be transient, particularly for populations at the transition between energy and water limitation. 
The effects of climatic change may be particularly strong in mountains, because warmer temperatures affect the depth and duration of snowpacks (Cayan, 1996; Mote et al., 2005; Knowles et al., 2006), which are key limiting factors for tree growth at high elevation (Peterson and Peterson, 2001; Nakawatase and Peterson, 2006; Case and Peterson, 2007). Population changes at upper treeline (e.g., Lloyd and Graumlich, 1997) and lower treeline (e.g., Allen and Breshears, 1998) are also linked to climatic variability, with the edge between forested ecosystems and other vegetation types (e.g., grassland, shrubland, or alpine meadows) clearly changing with decadal and centennial climate variability. Climatic influences are difficult to assess in mountainous areas, however, because complex topography produces steep gradients in the biophysical environment, and climatemonitoring stations are sparsely distributed, particularly at the highest elevations. (Thornton et al., 2000; Daly et al., 2008).

Two important disturbances in forests of the Pacific Northwest are wildfire and outbreaks of the mountain pine beetle (MPB -- Dendroctonus ponderosae). Wildfire has been linked to climatic variability via studies of Holocene charcoal sediments, fire-scar and stand-age reconstructions of fire history, and statistical models using 20th-century instrumental records (McKenzie et al., 2004 and references therein). Of particular concern are increases in fire area in a warming climate and the effects of extreme wildfire events on ecosystems (Gillett et al., 2004; Gedalof et al.,2005; Lutz, 2008; Littell et al., in press). For example, in 2006, the Tripod Complex Fire in north-central Washington burned over 80,000 ha, much of it higher severity than expected from historical fires.

Mountain pine beetle infestations have historically occurred frequently and extensively throughout the Pacific Northwest (Wellner, 1978; Logan and Powell, 2001). Climate change, in particular warming and drought, affects bark beetle life stage development rates, winter mortality, and host tree susceptibility (Logan and Powell, 2001; Carroll et al., 2004; Oneil, 2006). Across the West, stand structural conditions make host species susceptible to beetle attack (Hicke and Jenkins, 2008), future climate change is predicted to reduce the area of climate suitability for the MPB at low elevations, and increase climate suitability at higher elevations (Hicke et al., 2006).

Although the nature, timing, and impacts are only beginning to be understood, synergistic interactions between disturbances are producing larger effects than would occur from either disturbance independently (McKenzie et al., 2008). For example, MPB outbreaks have been linked to the increased likelihood of stand-replacing fire and changes in fire behavior, with the nature of the effect depending on the time since infestation (Lynch et al., 2006; Jenkins et al., 2008). Combined with increasing climatic stress on tree populations and growth, such disturbance interactions can alter forest structure and function more rapidly than could be predicted from models of species redistribution or disturbance alone. Simultaneous climatically driven shifts in the locations of species' optima, ecosystem productivity, disturbance regimes, and the interactions between them could reset forest succession over large areas and short time frames compared to changes observed during the $20^{\text {th }}$ century. Yet there is still substantial uncertainty surrounding future climate and ecosystem responses, much less interactions between them, particularly at regional and sub-regional scales. 
Planning for the impacts of climate change on forests requires better understanding of the role of climate in forest ecosystem processes. In this paper, we examine four key processes in forest ecosystems that we expect to change significantly across Washington State in a warming climate:

- Douglas-fir productivity and water limitation. Douglas-fir is one of the most widespread tree species in Washington, the most important by far economically, and possibly one of the more climate-sensitive species regionally. How will future changes in climate alter Douglasfir productivity in different parts of its range? Can we further identify the geographic domain of future water limitation in Washington forests?

- Conifer species ranges. Management priorities for forest ecosystems in Washington depend on species composition. How will climate change affect species distributions, particularly in sensitive areas where species are near the edges of their climatic tolerances?

- Fire area burned. The area burned by fire is predicted to increase across western North America as a result of climate change, but what are the expectations for Washington State and their consequences?

- Mountain pine beetle outbreaks. In the last decade, MPB outbreaks have increased in the West and appear to be correlated with warmer temperatures and drought. What are the specific consequences within Washington State?

To answer these questions, we use historical climate data, statistical ecological models, and climate (regional and global) and hydrologic simulation models to quantify the magnitude and direction of climatic influences on each forest ecosystem process. We then examine the relative importance of each of these processes for the structure, composition, and extent of Washington State forests under different scenarios for climatic change (Mote and Salathé 2009, this report). We address both the magnitudes of effects and the temporal scales at which they operate because when the magnitude and direction of two different changes are equal, those that occur over shorter periods will appear more sudden and be more difficult to anticipate. We use both composite climate model output and scenarios based on individual climate models, statistically downscaled to $1 / 16^{\text {th }}$ degree resolution (Salathé et al. 2007; Mote and Salathé 2009, this report, Elsner et al. 2009, this report), for future projections.

These four processes are by no means the only ones that will be affected by climate change; there is much that is left untreated by our emphasis on these four areas, and in most cases much more that could be said about the four we chose to emphasize. This assessment should be regarded as a first step, not an all-encompassing review.

\section{Methods}

\subsection{Productivity: Douglas-Fir Growth and Changes in the Area of Water-Limited Forest}

We explored the role of climate in the productivity of WA forests in two ways. First, we assessed potential changes in Douglas-fir growth for the period 1916-2003 (the period of time for which both tree cores and climate 
data exist) using growth increment measurements from 117 unmanaged stands in the Pacific Northwest (Littell et al., 2008). The sampled stands come from a wide range of local environments and represent a gradient of climatic conditions from maritime (e.g., western Olympics and western Cascades) to continental (e.g., eastern Cascades, north Idaho Panhandle, western Northern Rockies). We extended the work of Littell et al. (2008) by analyzing controls on absolute growth rather than focusing just on variability in growth. We developed stand-level basal area increment (BAI, a measure of annual radial growth) time series from 5-15 (mean $=10$ ) canopy-dominant or co-dominant trees in each stand. Raw treering series were measured to $0.02 \mathrm{~mm}$ (Littell et al. 2008) and converted to BAI following Nakawatase and Peterson (2006). We used Pearson correlations to assess the relationship between annual mean basal area increment and regional time series of summer climate variables (19162003 driving data and output variables from the VIC hydrologic model see Elsner et al. 2009, this report) previously linked to Douglas-fir growth: maximum temperature (Tmax), potential evapotranspiration (PET), actual evapotranspiration (AET), and water balance deficit (PET-AET).

Second, we evaluated the forested area in Washington that is currently energy-limited or marginally water-limited but likely to become severely water-limited during the mid $21^{\text {st }}$ century. We defined severely waterlimited forests as those forests where summer (JJA) PET exceeds annual precipitation; this is a conservative estimate of water limitation, but current areas of WA that meet this criterion are frequently ponderosa-pine woodland in transitional, low elevation forest habitat. This distinction of severe water limitation was made in order to emphasize the areas most likely to be impacted by changes in water deficit, but physiological limitations can occur before such limits are reached and the impacts are likely to be species dependent. We defined energy-limited forests as those where annual precipitation exceeds summer evapotranspiration. We used hydrologic simulations of current (1916-2006) and future (2020s, 2040s, and 2080s) annual PPT (precipitation) and summer PET (Elsner et al., 2009 , this report) to map future conditions of water limitation.

\subsection{Climate and Changes in Species Biogeography}

We assessed the potential for climate to alter important PNW tree species distributions by using spatially explicit projections from recently published analyses of climate and species responses for western North America (Rehfeldt et al., 2006). Specifically, we were most concerned with the potential for climatic stress on regeneration or mortality in Douglas-fir forests and the potential for stress in three species susceptible to the mountain pine beetle (lodgepole pine, Pinus contorta; ponderosa pine, Pinus ponderosa; and whitebark pine, Pinus albicaulis) in the PNW. Other species range changes are also important, but a full assessment is beyond the scope of this project. We focused on Douglas-fir because it is widespread and economically important and on the pine species because of their potential for interaction with the mountain pine beetle, particularly in forests east of the Cascades. For each species, we used Rehfeldt et al. (2006) grid maps of potential future habitat based on climate and combined these to develop summary maps of areas where climate is likely to exceed 
Rehfeldt et al.'s (2006) estimates of the tolerances of Douglas-fir. We used a similar approach to assess areas of change in pine species richness for the end of the 2040s-2060s (Rehfeldt's analyses are for the 2030s and 2060s). After Rehfeldt et al. (2006), we assumed that areas with $\geq 75 \%$ agreement among statistical climate/species models represented climatic conditions where the species was likely to occur. We assumed that areas with $<75 \%$ but $\geq 50 \%$ agreement were potential areas of future occurrence but where climatic variability might put the species at some risk, and we assumed that areas with $<50 \%$ agreement were unlikely to have sustained climatic conditions appropriate for species persistence and regeneration after disturbance.

\subsection{Climate and Area Burned by Fire}

We developed statistical models that relate area burned to climate at two different spatial and temporal scales. Prior to the 1980s, fire data from federally protected lands were aggregated from 1916 at the state level and therefore prohibit analysis for sub-regional vegetation types or at fine spatial scales. After 1980, analysis is possible at finer scales and agency reporting was consistently carried out at the agency unit (e.g., a USFS National Forest district, USDOI National Park, USDOI Bureau of Indian Affairs reservation, or USBLM district). There is therefore a tradeoff between the ability to incorporate more climatic variability inherent in the longer state-based dataset and the ability to assess climate-fire relationships by vegetation type in the shorter agency-unit-based dataset. We chose to develop regional models for the period 1916-2006 to assess the role of climatic variability on fire area burned in the PNW, and to develop finer models for 1980-2006 at the level of Bailey's ecosections (Bailey, 1995) for the Pacific Northwest ecosystems in Washington: Coast Ranges / Olympic Mountains, Puget Trough / Willamette Valley, Western Cascades, Eastern Cascades, Okanogan Highlands, Palouse Prairie, Blue Mountains, and Columbia Basin.

For the regional analysis (1916-2006), climate variables were domainaveraged observed climate data (Tmax, Tmin, PPT, Mote and Salathé, 2009 , this report). We used correlation analyses to identify potentially significant climatic drivers of area burned in the PNW, and these variables were iteratively entered as predictors in stepwise multiple linear regression models using AIC to arrive at the best model (Akaike Information Criterion - Akaike, 1974). AIC provides a metric, based on information theory, to optimize the tradeoff between model goodness-of-fit and parsimony (fewer parameters). The final regression maximized the variance explained by the model while retaining only multiple regression predictors significant at $\alpha$ $=0.1$ (usually 0.05 ). For ecosection analyses, the above procedure was repeated with ecosection-averaged climate variables (1980-2006, Tmax, Tmin, PPT, PET, AET, and PET-AET, or deficit, Elsner et al. 2009, this report) and for ecosection area-burned time series.

For both scales of inquiry, we then used future climate projections from the 2020 s, 2040s, and 2080s in the regression equations to develop projected area burned for the region and for each ecosection in WA. For the regional climate modeling, we used the ECHAM5 and CGCM-t47 A1B projections (Mote and Salathé 2009, this report) and for sub-regional ecosection 
models, we used ecosection-average composite downscaled projections and hydrologic model output (Variable Infiltration Capacity, see Elsner et al. 2009, this report). Both methods superimpose the observed climate variability on future changes in mean values, so the extrapolated fire area burned assumes that the range of future interannual variability in climate is comparable to the 20th century. For the future regional area burned projections, we also calculated $95 \%$ exceedence probabilities (the probability that a given year would exceed the $95 \%$ quantile in the 19162006 record) for the 2020s, 2040s, and 2060s.

\subsection{Climate and the Mountain Pine Beetle}

\subsubsection{Host Vulnerability}

We used data on $20^{\text {th }}$ century mountain pine beetle (MPB) outbreaks, climate conditions, and site and stand inventories to develop generalized linear models of the likelihood of successful attack by MPB for lodgepole pine forests of eastern Washington (Oneil 2006). We then projected these models onto future climate space to estimate the magnitude of future MPB impacts on Washington State forests.

To identify key variables associated with mountain pine beetle attack, we built upon the empirical predictive models of Oneil (2006), which found that vapor pressure deficit (VPD) variables, including average summer VPD, maximum VPD and length of time VPD exceeded certain thresholds were the best predictors of MPB attack for the epidemic starting in 2000. Summer VPD, the difference between the amount of water vapor held in the atmosphere at saturation vapor pressure and the amount of water vapor that could be held at average daylight temperature, was the best predictor of the number of MPB attacks during the warm dry summers of 2000 to 2003. These models took advantage of two extensive databases for eastern Washington, the Current Vegetation Survey (http://www.fs.fed.us/ r6/survey/) and the Department of Natural Resources' Forest Health Aerial Survey (www.fs.fed.us/r6/nr/fid/as/index.shtml).

We explored generalized linear models of two types, the Poisson and negative-binomial families (Venables and Ripley, 2002), to estimate counts of the total number of attacks over the period of record (after Oneil, 2006). We tested a variety of predictors and interaction terms and retained the models with the minimum AIC (Akaike, 1974).

Projections of future climate for the host-vulnerability analysis were derived using methods described in the Scenarios chapter (Mote and Salathé 2009, this report) for composite future projections, because we needed daily data to compute some of the predictor variables used in Oneil (2006). The composite delta values (change in temperature, Tdelta and change in precipitation, Pdelta) for each time period and emission scenario were added to a historic time series (1980-2003) of daily weather data generated using the DAYMET model (www.daymet.org) -- the same data used to build the models in Oneil (2006). These results generated plot-specific estimates of climate conditions for the six scenarios: 2020s, 2040s, and 2080s for A1B and B1 emissions scenarios. We increased the historical Tmax and Tmin values equally by Tdelta, and averaged the resulting future Tmax and Tmin to obtain a daily average temperature. 
From these, we calculated daily dewpoint temperature (Tdew), daily VPD, and daily Potential Evapotranspiration (PETday). For PETday, we used the methods of Lutz (2008), which correct for slope, aspect, and elevation. We also calculated the number of days VPD exceeds two different thresholds for each plot (hence the need for daily data). We used methods from Kimball et al. (1997) to adjust VPD estimates for arid and semi-arid regions where minimum daily temperature may not be sufficiently low to reach the dewpoint temperature.

We projected both models onto the future scenario composite data sets (Mote and Salathé 2009, this report), across our entire model domain (lodgepole and ponderosa pine forests of eastern Washington). Predicted values from the models, using the future data, were examined carefully to see if they suggested that we were extrapolating too far outside the ranges of the predictor variables used to build the models.

\subsubsection{Adaptive Seasonality: Temperature Effects on the Lifecycle of the Mountain Pine Beetle}

We evaluated the effects of changes in year-round (all seasons, hourly data) temperatures on the climatic suitability for mountain pine beetle outbreaks. The mountain pine beetle's life cycle is primarily controlled by temperature (Logan and Bentz, 1999; Powell and Logan, 2005). We employed a process model (developed from laboratory measurements of life-stage development rates as functions of temperature) that simulates the timing of all eight life stages of the mountain pine beetle (Bentz et al., 1991; Logan and Amman, 1986, Logan et al., 1995; Logan and Powell, 2001). The model computes a developmental index in each life stage by combining the annual course of hourly temperatures with the life-stage development rate. This index simulates life-stage development from egg through adult using input temperatures, and estimates time spent in each life stage.

"Adaptive seasonality" refers to beetle life cycle timing that is conducive to rapid reproduction, synchronized mass attacks on trees, and high survival rates in winter. This condition is predicted by the model when temperatures influence life-stage development rates such that: 1) the simulated population completes a life cycle in one year (instead of two);2) the population is synchronized for mass attacks on host trees as indicated by a life cycle exactly one year long; and 3) adult emergence from brood trees occurs at a suitable time of year (late summer) to permit the most coldresistant life stages to occur during winter. The model was successfully evaluated in a region in central Idaho that experienced a rapid increase in mountain pine beetle populations in the late 1990s (Logan and Powell, 2004). Long-term changes at coarse spatial resolution were evaluated with this model across the West by Hicke et al. (2006).

In this study, we used historical (1970-1999) temperatures to predict recent adaptive seasonality. We also estimated future (2070-2099) temperature suitability for two future climate scenarios (ECHAM5 and HADCM, A1B SRES scenario). Hourly temperatures were estimated from daily minimum and maximum temperatures by simulating a sawtooth pattern of hourly temperatures (Hicke et al., 2006). 


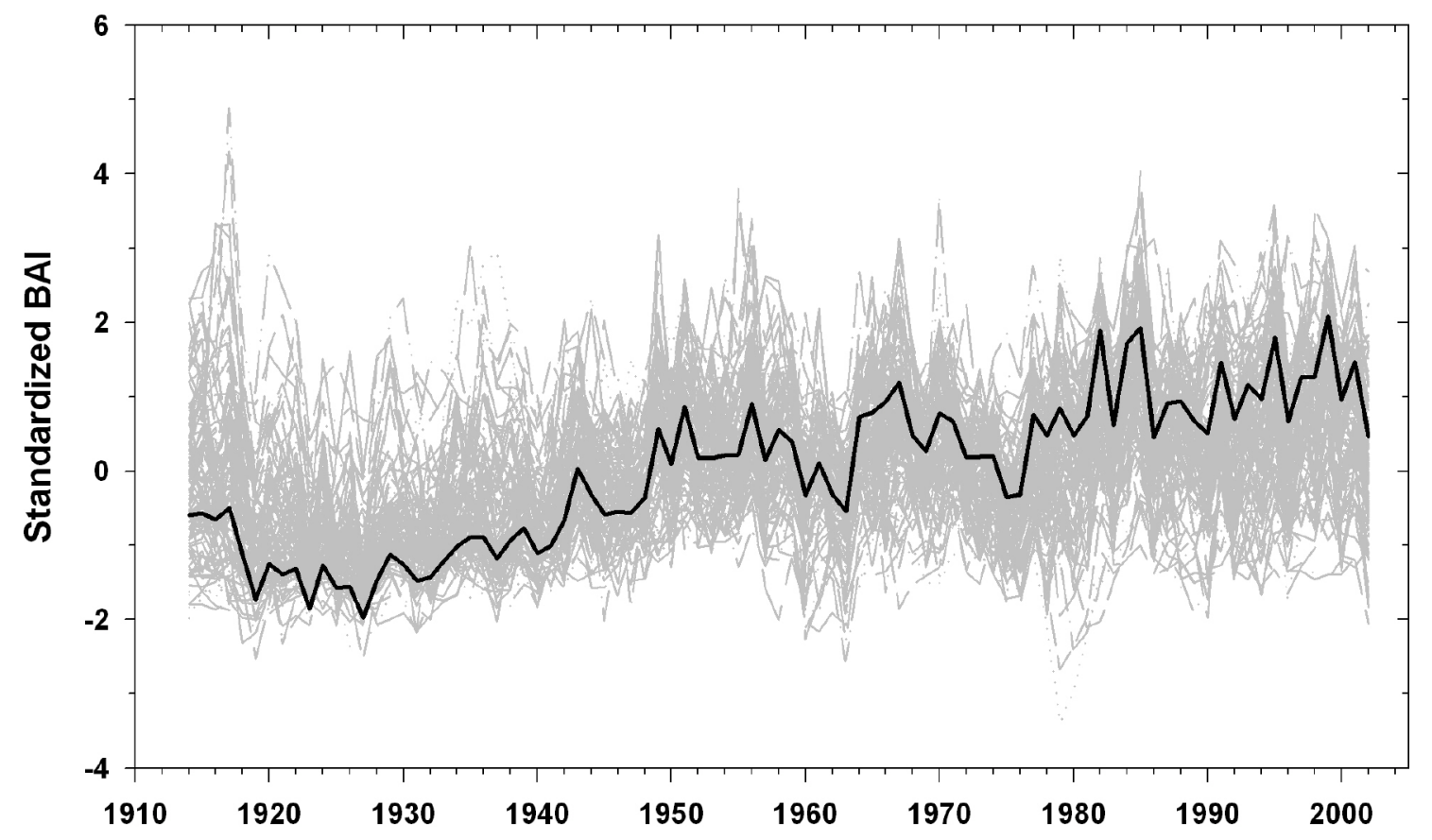

Figure 3. Douglas-fir network BAl time series 1914-2002. Gray traces represent plot-level time series, the black line is the mean of all series. Positive standardized BAI is higher than normal growth, negative standardized $\mathrm{BAl}$ is lower than normal growth. Trend and variability are both present.

\section{Results}

\subsection{Productivity: Douglas-Fir Growth and Changes in the Area of Water-Limited Forest}

Douglas-fir growth in the PNW was highly variable in space and time during the $20^{\text {th }}$ century (Littell et al., 2008), and this variability was generally correlated with variables indicating water limitation (e.g., positively correlated with summer precipitation and actual evapotranspiration but negatively correlated with summer maximum temperature and potential evapotranspiration). The strength of the correlation between water deficit and tree growth depends on the location of the stand along a gradient of mean summer water deficit - the most water-limited stands had the greatest sensitivity. The mean BAI time series has a small but significant increasing trend of about $13 \mathrm{~mm}^{2} / \mathrm{yr} /$ tree (Figure 3), and we could not attribute this growth trend to any single climatic factor, although there are weak but significant positive correlations with minimum temperature. The interannual variability about the trend in BAI (Figure 3) is not sufficiently explained by climatic variables to warrant statistical modeling of projected future productivity, but it is best correlated $(\mathrm{r}=0.42)$ with year prior JulyAugust water balance deficit averaged over the sampled watersheds. The area of WA forest that is severely water-limited will increase by $32 \%$ in the 2020 s, and an additional $12 \%$ in both the 2040s and the 2080s (all values relative to $20^{\text {th }}$ century water-limited forests, Figure 4$)$. 
Figure 4. Increase in area of severely water-limited forests in WA. The Okanogan highlands and the foothills of the northeastern Cascades contain most of the area that climate projections indicated will transition from energy- to water-limited forest by the 2080s.

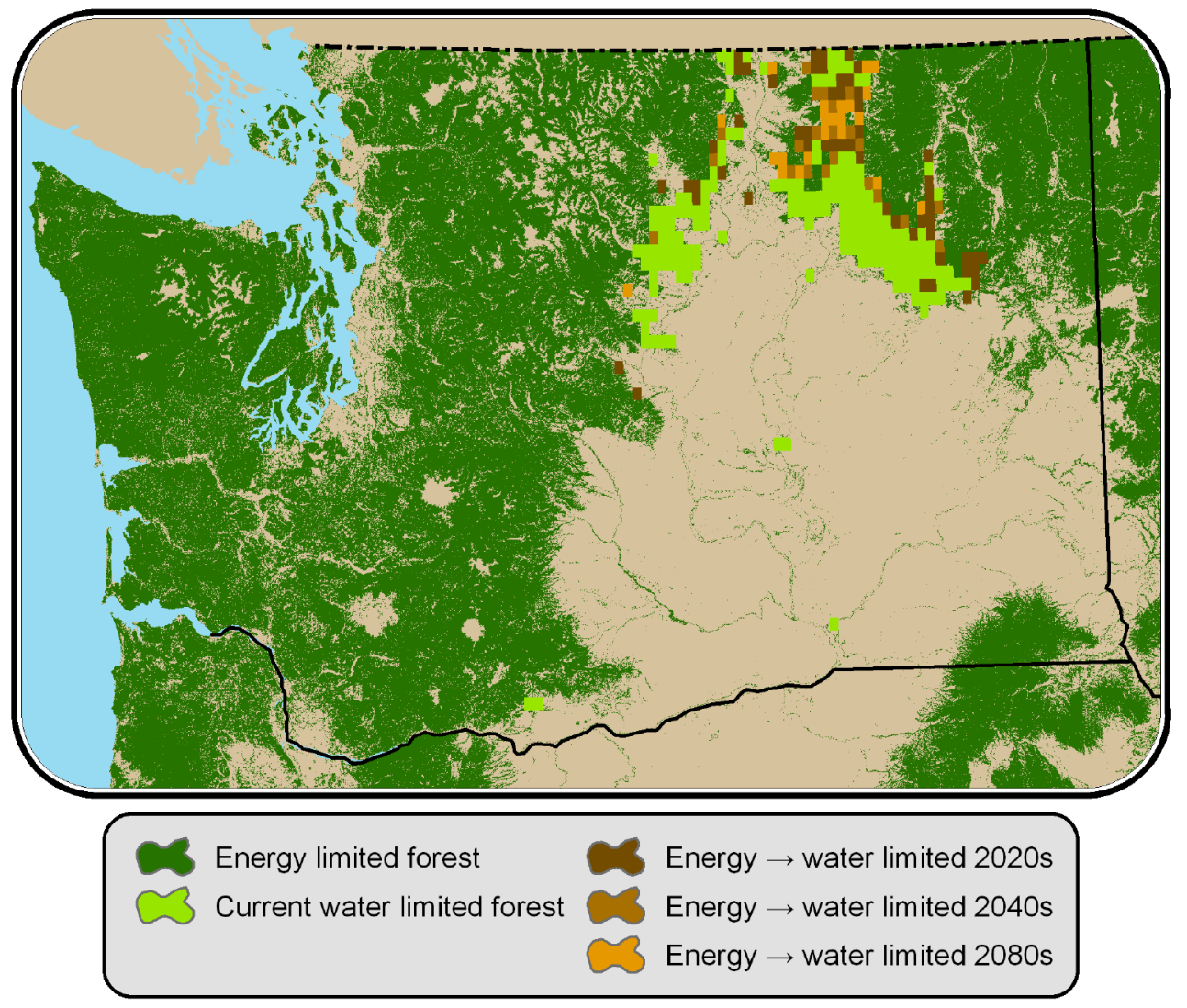

Figure 5. Change in area for which climate is suitable for Douglas-fir in the 2060s. Orange indicates area where fewer than $50 \%$ of the statistical models suggest climate appropriate for Douglas-fir presence in the 2060s. Dark green indicates areas where more than $75 \%$ of statistical models agree that climate is approrpriate for Douglas-fir. Data from Rehfeldt et al. (2006).

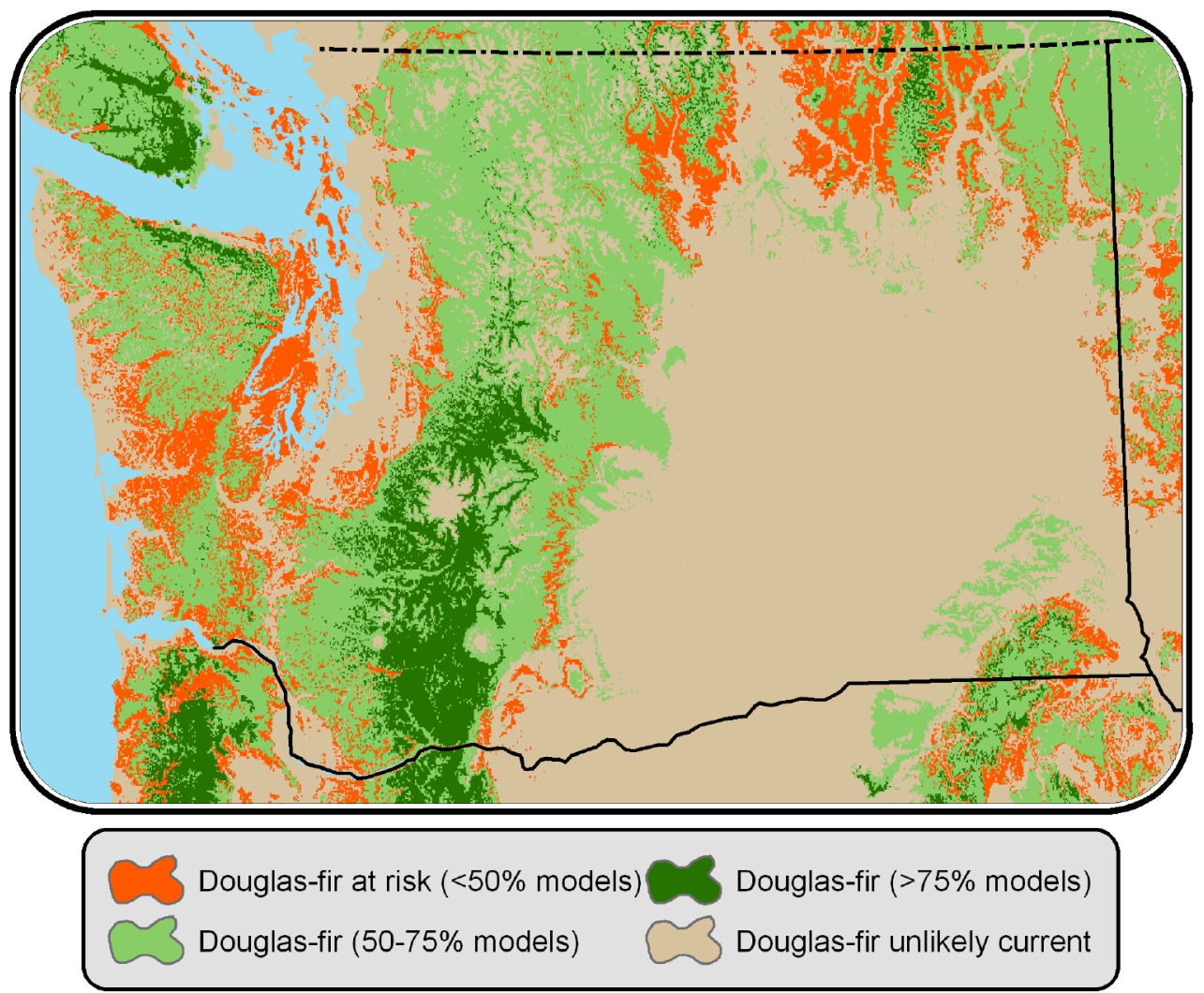




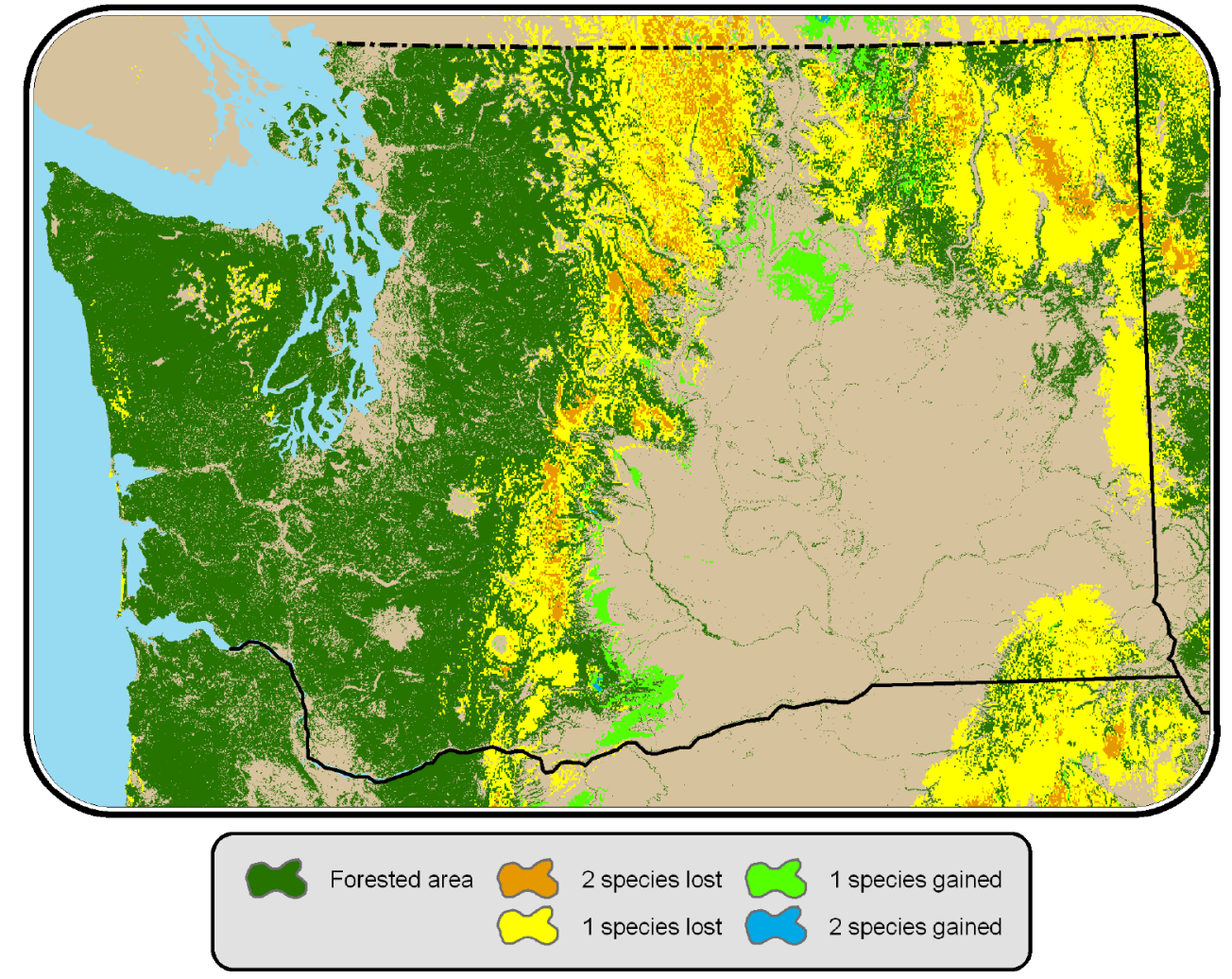

Figure 6. Change in number of pine species for which climate is suitable in the 2060s. Declines indicate places where climate is no longer suitable for species, while increases indicate places where climate is currently unsuitable and will become so. Areas in the Columbia Basin with gains projected by statistical models frequently already have patchy cover of ponderosa pine, whereas areas with gains at higher elevations in the Okanogan highlands likely represent upward migration of suitable climate for one or more pine species. Data from Rehfeldt et al. (2006).

\subsection{Climate and Changes in Species Biogeography}

By the end of the 2060s, independent species range modeling based on IPCC scenarios (a medium emissions scenario for both HadCM3 and CGCM2, Rehfeldt et al. 2006) suggests that climate will be sufficiently different from the late $20^{\text {th }}$ century to constrain Douglas-fir distribution (Figure 5). This is probably due to increases in temperature and decreases in growing season water availability in more arid environments (e.g., in the Columbia Basin) but could be due to other variables in less arid parts of the species' range. About $32 \%$ of the area currently classified as appropriate climate for Douglas-fir would be outside the identified climatic envelope by the $2060 \mathrm{~s}$, and about $55 \%$ would be in the $50 \%-75 \%$ range of marginal climatic agreement among models. Only about $13 \%$ of the current area would be climatically suitable for Douglas-fir in $>75 \%$ of the statistical species models. The decline in climatically suitable habitat for Douglas-fir is most wide-spread at lower elevations and particuarly in the Okanogan Highlands and the south Puget Sound / southern Olympics.

Climate is likely to be a significant stressor in pine forests in the Columbia Basin and eastern Cascades as early as the 2040s, particularly in parts of the Colville National Forest, Colville Reservation, and central Cascades (Figure 6). Of the area that is climatically suitable for at least one pine species, only $15 \%$ will experience climate consistent with no net loss of species; $85 \%$ will be outside the climatically suitable range for one or more current pine species ( $74 \%$ loss of one species, $11 \%$ loss of two species, $<1 \%$ loss of three species). 


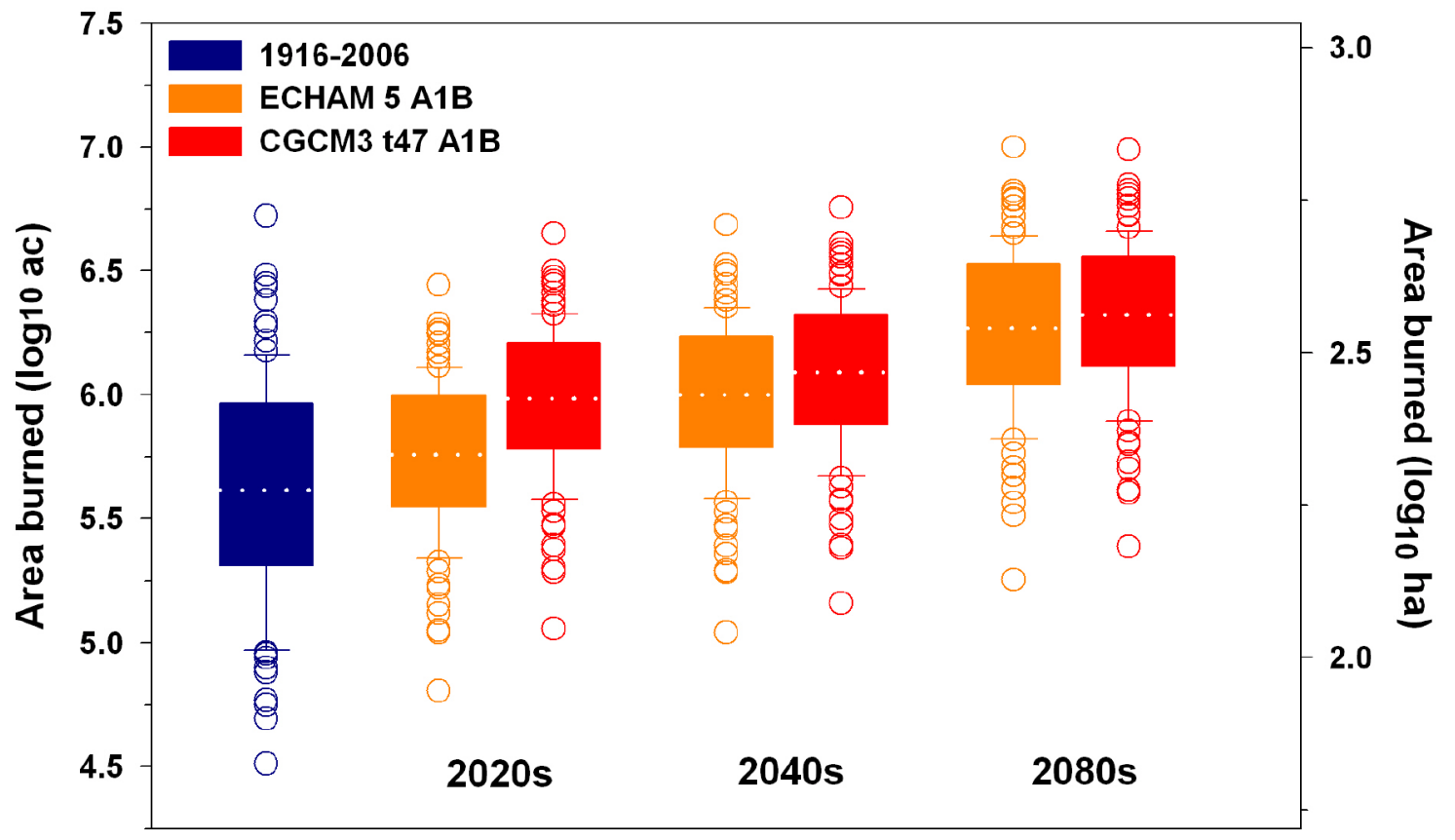

Figure 7. Changes in the distribution of annual area burned for the 2020s, 2040s, and 2080s for two "medium" scenario GCMs (Echam5 and CGCM_ t47). The white dashed line inside each box indicates the median area burned. To compute actual area burned, use a value on the logarithmic Y-axis as a power of ten (e.g., 10^Y).

\subsection{Climate and Area Burned by Fire}

Regional fire models suggest that summer precipitation and temperature play a large role in the area burned by fire. About half the variance in annual regional area burned can be explained either by July and August temperature and precipitation or July and August water-balance deficit; the best model includes June-August total precipitation (negative relationship with fire), July-August average temperature (positive), and January precipitation (negative - total November to March precipitation performs similarly). Future fire projected from the best statistical model suggests a doubling or tripling of area burned by the 2080s (Figure 7). The median regional area burned, averaged over both $\mathrm{GCMs}$, is projected to increase from about 0.5 million acres $(0.2 \mathrm{M} \mathrm{ha})$ to 0.8 million acres $(0.3 \mathrm{M} \mathrm{ha})$ in the $2020 \mathrm{~s}, 1.1$ million acres $(0.5 \mathrm{M}$ ha) in the $2040 \mathrm{~s}$, and 2.0 million acres $(0.8 \mathrm{M} \mathrm{ha})$ in the $2080 \mathrm{~s}$. The probability of exceeding the $95 \%$ quantile area burned for the period 1916-2006 increases from 0.05 to 0.48 by the 2080s (Table 1).

Sub-regionally, the strongest models occur in drier forest types and shrubland ecosystems ( $>55 \%$ variance explained by climate), whereas

Table 1. Modern and projected future exceedence probabilities for PNW regional area burned. 95\% Exceedence (yr) refers to the count of years in a future record equivalent to the study record that would exceed the historical 1916-2006 95\% quantile area burned; Exceedence (p) refers to the probability of a year exceeding the 1916-2006 95\% quantile in the future.

\begin{tabular}{|l|c|c|c|c|c|c|c|}
\hline & Modern* & \multicolumn{2}{|c|}{ 2020s } & \multicolumn{2}{c|}{ 2040s } & \multicolumn{2}{c|}{ 2080s } \\
\hline Exceedence & & ECHAM5 & CGCM3 & ECHAM5 & CGCM3 & ECHAM5 & CGCM3 \\
\hline $\mathbf{9 5 \%}(\mathbf{y r})$ & 5 & 1 & 8 & 10 & 20 & 43 & 44 \\
\hline $\mathbf{9 5 \%}(\mathbf{p})$ & 0.05 & 0.01 & 0.09 & 0.11 & 0.22 & 0.47 & 0.48 \\
\hline Number of yr > 1M ac & 23 & 23 & 44 & 47 & 61 & 74 & 79 \\
\hline Number of yr > 3M ac & 2 & 0 & 2 & 5 & 8 & 30 & 34 \\
\hline
\end{tabular}



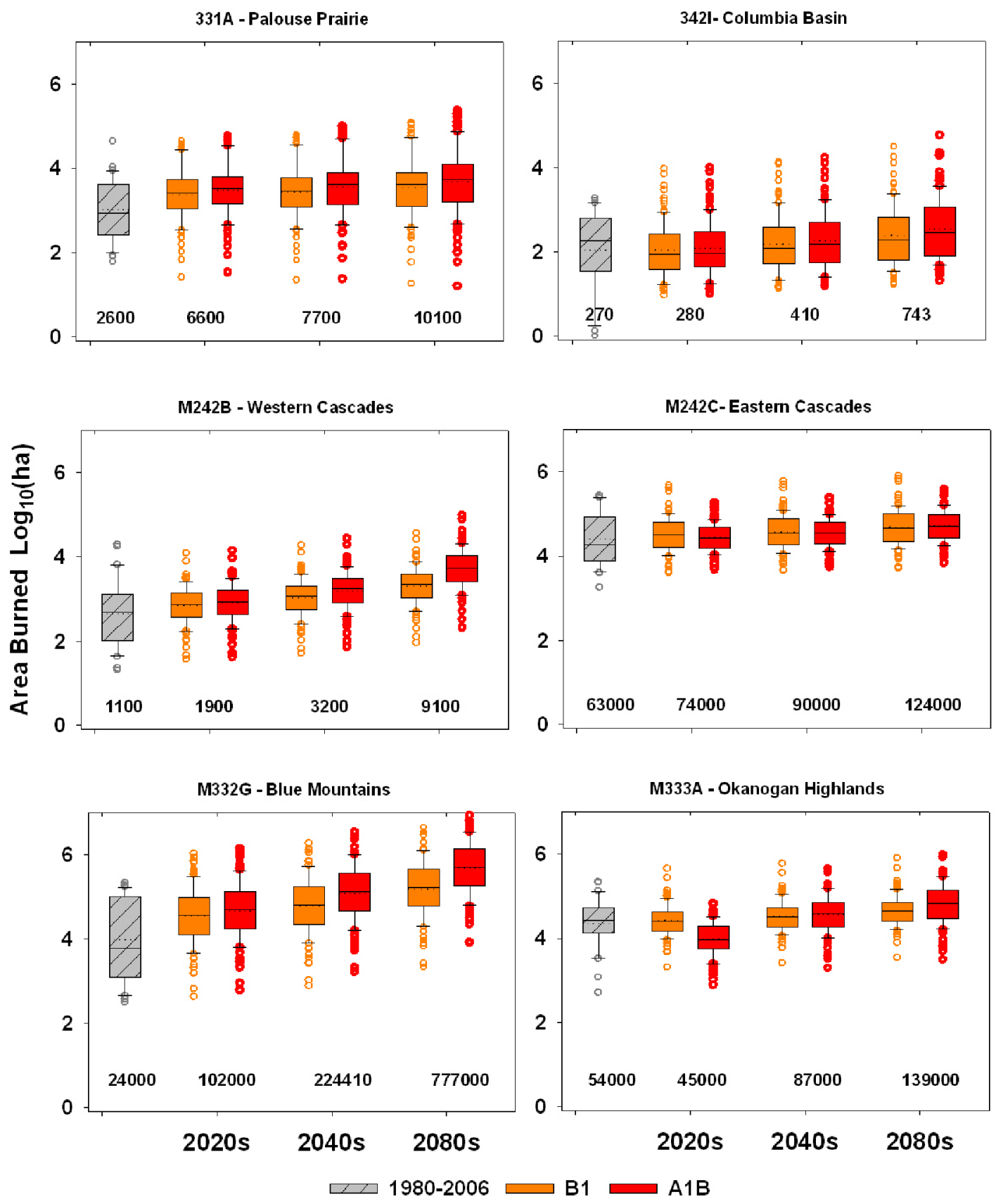

Figure 8. Projections of future area burned in WA ecosections for which statistical fire models could be constructed. All model projections were based on delta-method composite future climate (Mote and Salathé 2009, this report). The text numbers below each set of boxand-whiskers plots indicate the average of A1B and B1 future area burned estimates for the ecosections in acres. 
west of the Cascades, the relationship between fire and climate is weaker and statistical models are difficult, if not impossible, to construct due to the low annual area burned. Models including potential evapotranspiration or deficit frequently performed better than those that relied on temperature, precipitation, and their interactions. Projections of future fire in the wetter ecosections generally have greater uncertainty, and other methods with a more mechanistic treatment of fire, weather, and climate will be required to fully understand the future role of fire in these ecosystems.

We were successful in developing statistical models of area burned for 6 of the 8 ecosections in Washington for the period 1980-2006; the Coast Ranges/Olympic Mountains and Puget Trough / Willamette valley sections had low annual area burned and low varaibility and did not yield strong regression models. The other six ecosections yielded regression models that explained between 50 and $65 \%$ of the variability in area burned. The most important explanatory variable in five of the eight models was either potential evapotranspiration or water balance deficit (PET-AET), and two models had July-August Tmax terms. Lagged precipitation terms and lagged inverse deficit terms (wetter) were important in the Columbia Basin, Palouse Prairie, and Okanogan Highlands. Future projections from these six models project mean area burned increases of between 0 and $600 \%$ depending on the ecosystem in question, the sensitivity of the fire model, emissions scenario and the time frame of the projection (Figure 8). By the 2040s, the area burned in non-forested ecosystems (Columbia Basin and Palouse Prairie) increased on average by a factor of 2.2. In forested ecosystems (Western and Eastern Cascades, Okanogan Highlands, Blue Mountains) the mean area burned increased by a factor of 3.8 compared to 1980-2006. Notably, the increase in area burned is accompanied by an increase in variability in some of the more arid systems - Palouse Prairie and Columbia Basin. The largest proportional increases are in the Western Cascades and Blue Mountains, although the Western Cascades model was the weakest statistically acceptable model, and the area burned is still small despite the large proportional increase. The Blue Mountains model was extremely sensitive, and projected area burned increased at a rate faster than any other ecosection.

Table 2. Expected water deficit and precipitation changes for six future scenarios and historical DAYMET-based calculations

\begin{tabular}{|c|c|c|c|c|c|c|c|c|}
\hline \multirow[b]{2}{*}{ Scenario } & \multirow[b]{2}{*}{ Year } & \multicolumn{3}{|c|}{ Scenario climate } & \multicolumn{3}{|c|}{$\%$ Change from 1980-1999 } & \multirow{2}{*}{$\begin{array}{c}\text { \# Plots with } \\
\text { deficit } \\
>250 \mathrm{~mm}\end{array}$} \\
\hline & & $\begin{array}{l}\text { Mean water } \\
\text { deficit (mm) }\end{array}$ & $\begin{array}{c}\text { Annual } \\
\text { PPT (mm) }\end{array}$ & $\begin{array}{c}\text { Summer } \\
\text { PPT }(\mathrm{mm})\end{array}$ & $\begin{array}{c}\text { Mean water } \\
\text { deficit }\end{array}$ & $\begin{array}{c}\text { Annual } \\
\text { PPT }\end{array}$ & $\begin{array}{l}\text { Summer } \\
\text { PPT }\end{array}$ & \\
\hline \multirow[t]{3}{*}{ A1B } & 2020 & 142 & 1242 & 34 & $294 \%$ & $132 \%$ & $29 \%$ & 116 \\
\hline & 2040 & 177 & 1935 & 17 & $367 \%$ & $206 \%$ & $15 \%$ & 228 \\
\hline & 2080 & 209 & 2831 & 12 & $432 \%$ & $302 \%$ & $11 \%$ & 442 \\
\hline \multirow[t]{3}{*}{$\mathrm{B} 1$} & 2020 & 93 & 1604 & 88 & $193 \%$ & $171 \%$ & $75 \%$ & 27 \\
\hline & 2040 & 114 & 1756 & 70 & $236 \%$ & $187 \%$ & $60 \%$ & 18 \\
\hline & 2080 & 158 & 2199 & 29 & $326 \%$ & $235 \%$ & $25 \%$ & 116 \\
\hline Historical & $2000-03$ & 96 & 767 & 60 & $199 \%$ & $82 \%$ & $51 \%$ & 33 \\
\hline Historical & 1980-99 & 48 & 937 & 118 & $100 \%$ & $100 \%$ & $100 \%$ & 2 \\
\hline
\end{tabular}


Our analysis of host vulnerability identified a substantial change in the average water deficit across all sites within the current range of lodgepole pine (Table 2). Even though all future scenario projections indicate an increase in annual precipitation over the pre-2000 period average (Mote and Salathe 2009, this report), the summer water deficit increases two to three times because of reduced summer precipitation and increased temperature. This is consistent with hydrologic assessments suggesting reduced snowpack, reduced summer soil moisture, and increased PET (Elsner et al. 2009, this report). In Washington State, lodgepole pine is rarely found on sites with climatic water deficit $>250 \mathrm{~mm}$ (two of 1630 plots). In both the B1 and A1B climate scenarios, the climatic water deficit of plots currently occupied by lodgepole pine increasingly extends beyond the envelope where lodgepole pine currently exists. These projections of deficit suggest that areas with climatic conditions favorable for lodgepole pine will decrease considerably; $27 \%$ plots will be subject to more water stress than those under the most stress today.

Table 3. Summary statistics for the predictive model of MPB attacks. Two predictors were not significant at $\alpha=0.05$, but were part of highly significant interactions.

\begin{tabular}{|l|r|}
\hline Predictor & p-value \\
\hline 1) MaxVPD (when exceeds 2 kPa) & 0.167 \\
\hline 2) Pre-growing season PPT & 0.393 \\
\hline 3) AvgVPD (Jun, Jul, Aug) & 0.031 \\
\hline 4) DaysVPD exceeds $1.5 \mathrm{kPa}$ & $<0.001$ \\
\hline 5) First DayVPD (exceeds $1.5 \mathrm{kPa}$ ) & $<0.001$ \\
\hline 6) Interaction of \#1 and \#3 & 0.024 \\
\hline 7) Interaction of $\# 4$ and $\# 5$ & $<0.001$ \\
\hline
\end{tabular}

These projections of deficit suggest that areas with climatic conditions favorable for lodgepole pine will become increasingly rare because trees will be subject to significantly more water stress with a correspondingly greater VPD. The best statistical model of MPB attack -- a negativebinomial family GLM -- found VPD-based variables and their interactions to be the most significant predictors of the number of attacks over the historical period of record, 2000-2003 (Table 3). Interpretation of the models is not straightforward, however, with five predictors and their interactions.

Plots of fitted values against MaxVPD and AvgVPD (not shown) suggest that the greatest likelihood of attack comes when mean conditions are hot and dry, but not exceptionally so, and there is a fairly short period of extreme VPD during which trees are extremely vulnerable because they are not physiologically adapted to maintain water balance under such conditions 


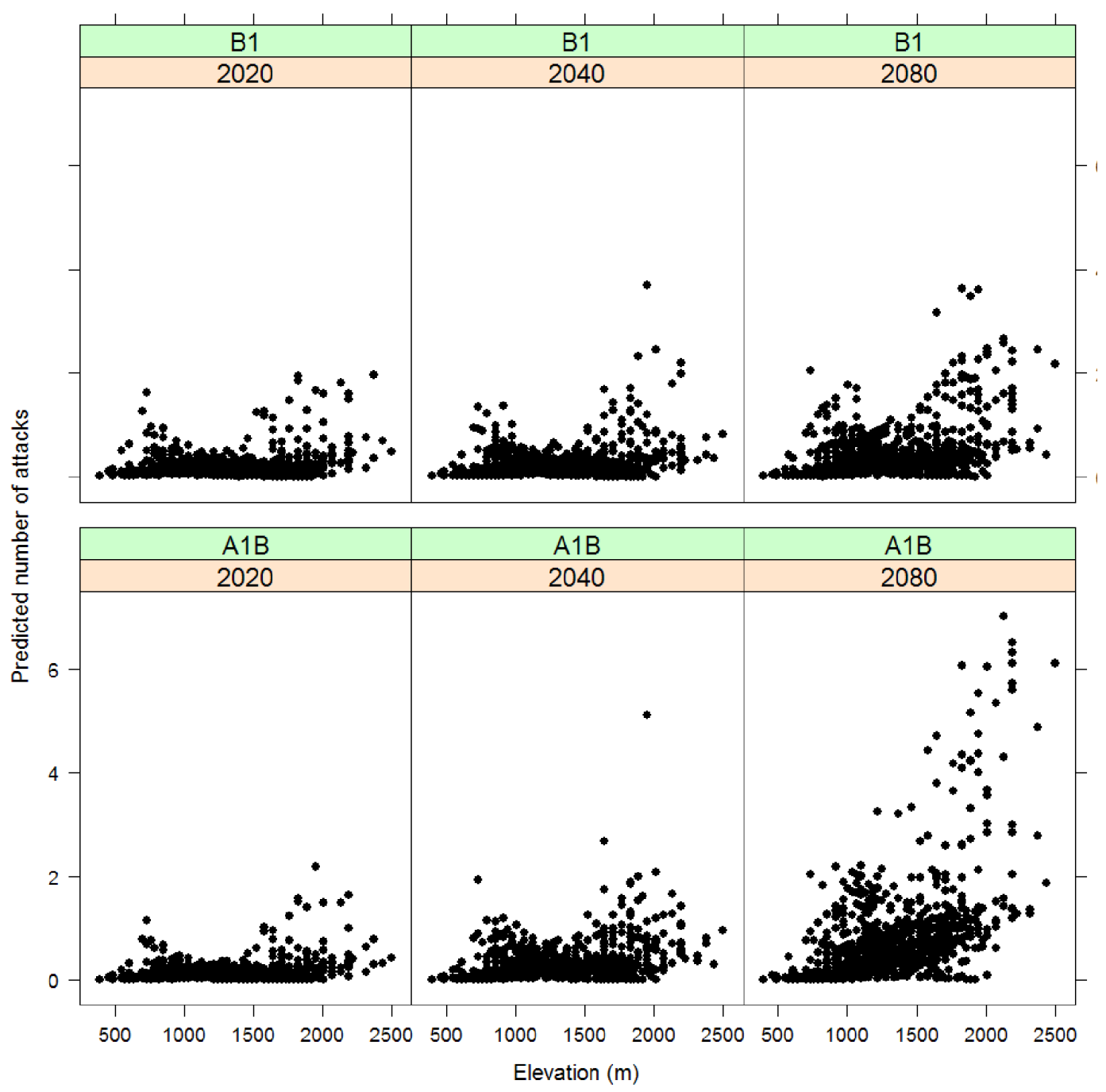

Figure 9. Changes in the number of predicted mountain pine beetle attacks (fitted values), with elevation, time, and emissions scenario. Models were fit for a 6-year period, so the maximum observed value of the response variable was 6 . Note that predicted values are not integers because they are fit from a negative-binomial GLM.
(Running and Waring 1998), which is integral not only to survival but also to their capacity to repel beetle attacks (Delucia et al., 2000).

Projecting the model into the future clearly suggests that attacks will be concentrated at increasingly higher elevations (Figure 9) because the climate conducive to outbreaks effectively shifts to higher elevations. In conjunction with expected elevational shifts of host species (lodgepole pine and ponderosa pine), and predictions from the adaptive seasonality model (see below), we expect mountain pine beetle outbreaks to be a continuing concern.

Based on the adaptive seasonality modeling, however, the area suitable for these outbreaks will decrease (Figure 10). Temperatures are currently suitable for MPB outbreaks in large areas of the Olympic Mountains, northern Rocky Mountains, in a band of mid-elevation on the west and east sides of the Cascade Mountains, and to a lesser degree in the Blue Mountains of southeastern Washington. However, simulations using climate change scenarios for 2070-2099 predict that the region of climate suitability will move higher in elevation as the climate warms (Figure 10), thereby reducing the total susceptible area. At lower elevations, increasing temperatures will cause asynchrony in adult emergence through more rapid life stage development as well as cause emergence at inappropriate times 

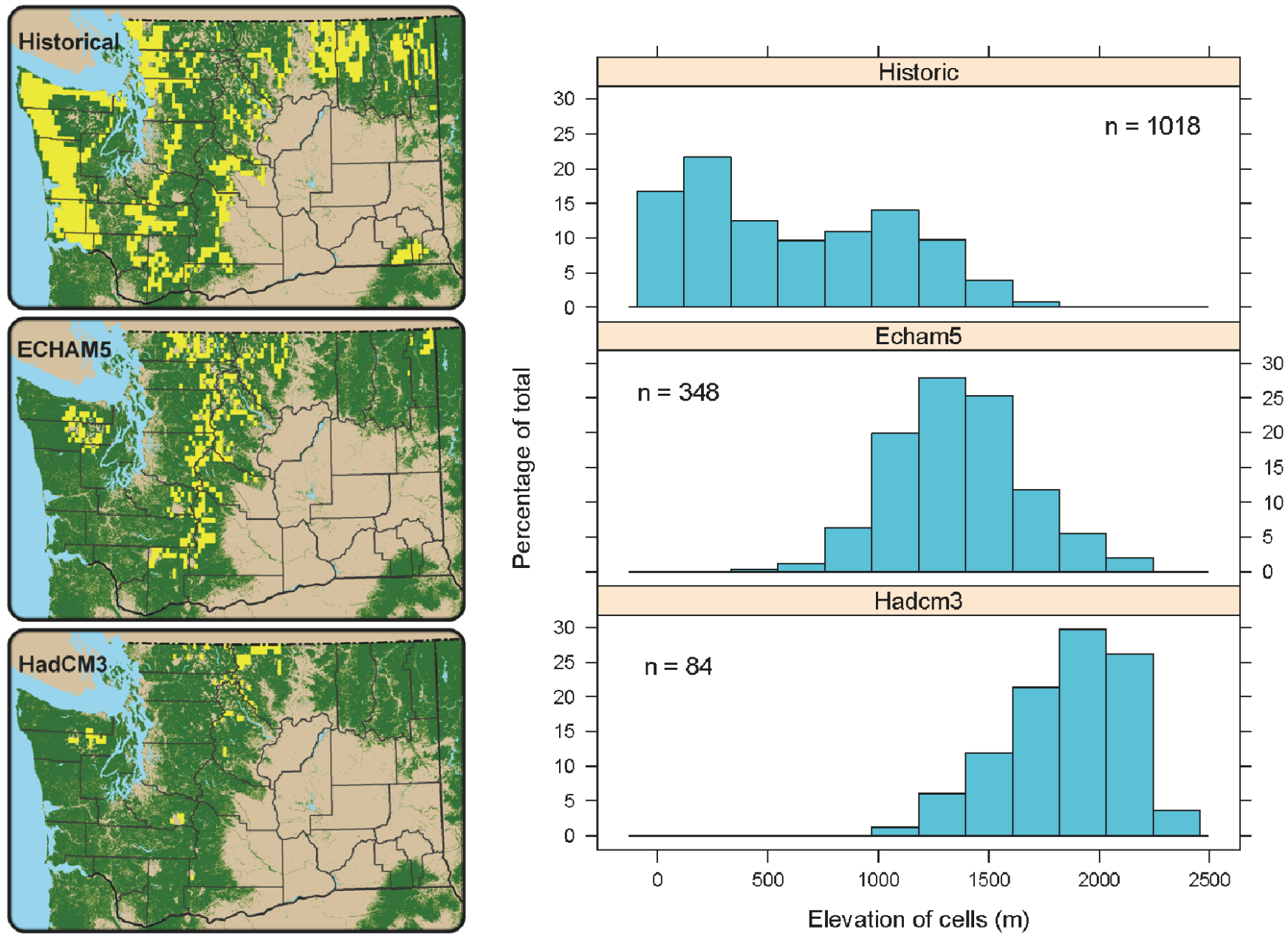

of year, reducing populations and decreasing the efficacy of mass attacks (Logan and Bentz, 1999). Higher elevations will warm enough to allow synchronous population emergence during a one-year time frame. For the ECHAM5 climate model (moderate warming), temperature suitability will occur at high elevations in the Olympic and Cascade Mountains. The area of adaptive seasonality is greatly reduced in the Rocky Mountains and is eliminated in the Blue Mountains. For the HADCM3 climate model (greater warming), only a few areas of adaptive seasonality remain, in the highest elevations of the Olympic Mountains and highest and most northern Cascade Mountains. These areas of future adaptive seasonality coincide with the current distribution of whitebark pine, but are mostly above the current elevational range of other susceptible species.

It is important to recognize, however, that these figures are snapshots in time. In fact, outbreaks of mountain pine beetle could occur across the areas "traversed" by the beetle between now and the late $21^{\text {st }}$ century as their climatic suitability moves upward in elevation. The low area of adaptive seasonality presented using the HadCM3 projection for the 2080s therefore belies the much larger area suitable for outbreaks in the interim. Furthermore, the average climate used does not capture interannual variability in future temperatures that may initiate outbreaks of mountain pine beetle earlier in time than suggested by these results.

Figure 10. Adaptive seasonality of mountain pine beetle in Washington forests for historical (1970-1999), ECHAM5, and HadCM3 future scenarios for the 2080s (SRES scenario A1B). Yellow cells are suitable space for the beetle. Histograms show the change in elevation distribution across scenarios for suitable cells with $\mathrm{n}=$ total cells with suitable climate for the MPB. 


\section{Discussion}

\subsection{Importance of Disturbance as Principal Player in Forest Change}

The direct impacts of climate on tree species (e.g., productivity, distribution) are important, but given the projected increases in fire area and MPB attacks at higher elevations, ecosystem changes caused by disturbance are likely to be greater, notwithstanding that disturbance has a more immediate impact on the ecological integrity of forest ecosystems and associated ecosystem services. It is likely in the future that the rate of forest change (forest type, species composition, productivity) in response to climate change will be driven more by disturbance than by gradual changes in tree populations (driven by impacts on life history characteristics and phenology) and will therefore be more rapid than climate-based analyses of future species range shifts indicate.

The combined projected increases in water limitation, area burned, increase in high elevation area of adaptive seasonality, and increase in host vulnerability suggest that few areas are immune to increasing disturbance. For example, although we were unable to build strong predictive models of future west-side fire, increasing summer Tmax and potential evapotranspiration suggest that large disturbances are likely in westside forests that have not traditionally been thought of as "fire prone". Elsner et al. (2009, this report) found that west of the Cascade crest, summer soil moisture is likely to decline substantially due particularly to increasing temperature. Some global climate models project decreases in summer precipitation for the region, whereas others project little change - few suggest increased precipitation. This suggests that future climatic conditions will decrease fuel moisture, and it is therfore reasonable to expect increased fire activity. Evidence from stand age classes also indicates that fires much larger than those in the modern record occurred centuries in the past (Agee and Flewelling 1983, Henderson and Peter 1981). The impacts of increasing disturbance, whether east-side or westside, are worthy of further study.

Some areas may also face novel disturbance interactions. For example, 20 th century land management (younger stands and possible loss of genetic diversity) may exacerbate the effects of fire and insect disturbance. The increasing tendency toward water limitation on the edges of the Columbia Basin and the projections for modified climatic ranges for ponderosa pine, Douglas-fir, and lodgepole pine strongly suggest that post-disturbance regeneration will proceed along different successional trajectories and different genotypes or species will be favored.

The increase in area burned is a strong result, but statistical models of area burned have some important limitations. Area burned should not be expected to increase indefinitely - statistically or ecologically. At some point, forests have been disturbed and climate has changed to the point where the disturbance regime does not resemble the modeled relationships any longer. On the other hand, some ecosection models (e.g., Okanogan Highlands, Eastern Cascades) show evidence of hydroclimatic facilitation offire, probably via increased fine fuels (Littell et al. in press), and future area burned could decrease if precipitation increases were insufficient to offset expected potential evapotranspiration or if summer precipitation decreased. 
The climate models we used are a hedge against such uncertainties - they are the models best able to reproduce the region's observed climate and the average of many possible future realizations. However, the variablity in future fire regimes has been necessarily underestimated here by using the composite mean and not an ensemble composed of all the available future climate models

Most evidence suggests that mountain pine beetle attacks in the future are likely to be more successful and beetle populations will be moving to higher elevations. An important uncertainty here is the timing of species range changes and the timing of beetle populations range changes - for beetle attacks to achieve epidemic status, a sufficient population of well established mature trees must be present to sustain the insects. If the impacts of fire and species turnover proceed quickly, spatial heterogeneity of age classes on the landscape may reduce beetle impacts significantly.

The strength of the relationships between climate and fire and climate and mountain pine beetles supports a hypothesis of climate-driven disturbance as the primary mechanism of change in the future forests of Washington. We were not able to assess the interaction between fire and mountain pine beetles quantitatively, but it is likely, for example, that MPB outbreaks will affect fuel structure and availability to fire (Lynch et al. 2006). A process model that considers this interaction and any potential synergies for impacts to forest ecosystems would be useful to project future conditions. Such a model should consider the relative importance of the two disturbances in future synergistic interactions, which depends on the presence of suitable host species and the fire regimes expected in those forest types. For example, high elevation whitebark pine ecosystems may have severe MPB mortality in the future without greatly influencing the area burned by fire because fuel availiability would not necessarily change dramatically in such low-density forests. On the other hand, nearly pure lodgepole pine forests, which are already strongly fire dependent, will potentially have altered fuel characteristics conducive to relatively rapid rates of fire spread, thus increasing the potential size of fires. We also did not study disturbance effects on forest management goals, such as wildlife habitat, timber products, or other ecosystem services, but because the area susceptible to disturbance impacts will be large, and strategies to mitigate the potential resource risks will need to carefully consider potential novel effects of altered disturbance regimes.

\subsection{Broad Characteristics of Future Forests in Washington}

Increasing water limitation appears likely across a significant portion of the northern Columbia Basin and eastern Cascades, if other factors (e.g., $\mathrm{CO}_{2}$ driven increases in water use efficiency) do not offset the climatically driven changes. Our definition of water limitation is conservative, and emphasizes the most severe limitation; much of the forested area we defined as energy limited in Washington is water limited for some portion of the year, but that limitation is not as severe as the areas highlighted in Figure 4. For those areas where annual precipitation is less than annual potential evapotranspiration (a less conservative definition of water limitation) there may still be important limitations on productivity and regeneration.

A caveat to the projections of future species-appropriate climate envelopes 
is that they fail to consider ecological factors that can exacerbate or mitigate the projected changes. For example, such models assume the climatic ranges they describe are equally applicable across all parts of a species' lifecycle, but the models are constructed on the presence or absence of established trees of many ages - not on seedlings, which are likely most susceptible to climate variability. We also do not consider the impacts of local soil limitations, nutrient limitations, changes in nitrogen deposition, all of which could affect productivity and species distribution locally in the future.

Many of Washington's future forests may look much like the forests that are currently present, but the most vulnerable forests may look radically different due to increased frequency and severity of disturbances. Eventually, species and stand densities that are resistant to increased summer water deficit and increased disturbance will be favored, and landscape structure and pattern will change. Particularly in places where vegetation types shift from forest to woodland or from tundra to forest, fire regimes will be influenced by the shift in vegetation; dynamic vegetation models that address the feedbacks between vegetation, climate, fire, and biogeochemistry are required to understand such processes. In the near term, however, such uncertainties are less important than the considerable impacts on Washington's current forest ecosystems.

All of the impacts assessed in this study are likely to occur by the 2040s at the northern edge of the Columbia Basin in the Okanogan highlands and in the northeastern North Cascades. The impacts of climate on fire regimes, insect attacks, tree water stress and both Douglas-fir and pine species' ranges will likely interact strongly in the north eastern Cascades, Okanogan Highlands, and Blue Mountains earlier rather than later in the $21^{\text {st }}$ century. Although less area burned is projected in the western Cascades and the Olympics and there is less area dominated by pines susceptible to MPB, it would be a mistake to conclude that impacts and their interactions will not be important in those ecosystems. For example, Douglas-fir will be outside of its optimal climate range over considerable areas, and there are almost certainly thresholds of water deficit past which large areas of west side forests would be at risk for large fires. Such fires do not occur in the $20^{\text {th }}$ century historical record, so statistical fire models are incapable of projecting them. However, even though we are unable to model large westside fires, hotter and drier summers unequivocally increase the chance that such fires will occur.

\subsection{Adaptation Options}

Adaptation options depend greatly on the scale in question (Table 4, Millar et al., 2007; Joyce et al., 2008). Regional adaptation is necessarily an exercise in forest policy and planning as much as it is engaging in landmanagement actions; it must be sufficiently flexible to facilitate adaptation locally but also capable of organizing regional responses. Local adaptation must be tailored to local conditions to succeed (all adaptation is necessarily local), but decisions that determine local action may be made at the state or federal level, requiring a regional or national viewpoint. Furthermore, given climate change and globalization, adaptation proceeds in a context defined as much by regional and global pressures as by local conditions 
Table 4. Examples of adaptation options (after Millar et al. 2007)

\begin{tabular}{|l|l|l|}
\hline Adaptation strategy & Regional actions (policy) & Local actions (management) \\
\hline Resist change & $\begin{array}{l}\text { Minimize impacts of disturbance, } \\
\text { suppress fire in systems where fire is } \\
\text { rare, but maintain Wildland Fire Use } \\
\text { (WFU) }\end{array}$ & $\begin{array}{l}\text { Suppress wildfire in wildland- } \\
\text { urban interface; }\end{array}$ \\
\hline $\begin{array}{l}\text { Promote resilience to } \\
\text { change }\end{array}$ & $\begin{array}{l}\text { Thin stands from below (to increase fire } \\
\text { resilience); create uneven-aged structures } \\
\text { or reduce density (to increase insect } \\
\text { resilience) }\end{array}$ & $\begin{array}{l}\text { Use large disturbances as } \\
\text { opportunities to establish } \\
\text { new genotypes, and forest } \\
\text { heterogeneity and diversity }\end{array}$ \\
\hline $\begin{array}{l}\text { Allow forest ecosystems } \\
\text { to respond to change }\end{array}$ & $\begin{array}{l}\text { Plant new species expected to respond } \\
\text { favorably to warmer climate }\end{array}$ & $\begin{array}{l}\text { Use new genotypes, or even } \\
\text { species, in forestry plantations }\end{array}$ \\
\hline
\end{tabular}

- no successful strategy can be crafted without awareness of these outside pressures.

Regional adaptation consists of strategies likely to promote conditions that increase the likelihood of a specific objective. Thinking about adaptation for forests is in many ways in its infancy, but examples might include stronger emphases on: reducing anthropogenic stresses on forest ecosystems, promoting resilience to likely impacts, landscape and biological diversity, planning for projected future conditions, and assessing the decision context in terms of barriers and opportunities that limit or facilitate local adaptation (Millar et al., 2007; Joyce et al., 2008).

Local adaptation consists of application of tools (existing or new) to affect conditions. First one must identify management objectives, assess capacity to alter conditions for the objectives, and then develop appropriate tools. For example, targeted thinning in drier forests in which fire suppression has led to fuel accumulations capable of sustaining a high severity fire (novel in those ecosystems) may increase the resilience of that forest to a fire. In wetter forests where $20^{\text {th }}$ century harvest practices have decreased age class diversity and altered patch structure, targeted thinning and cutting could simultaneously create appropriate fuel breaks and increase canopy and age-class diversity. In water-limited forests, it is possible that tailoring stand density to the expected water conditions of the future will increase resilience to insect attack and climate change in general by increasing stand water supply to counteract the projected increased atmospheric demand. Clearly, some general guidelines exist.

The management implications of climate impacts to forests and the resulting need for planning for and adapting to those impacts in the state of Washington are manifold. Obvious implications are that "forest types", "communities", disturbance return intervals, and historic ranges of variability are all concepts that attempt to define the state of a forest, but that state is inherently dynamic and thus defies easy categorization - climate change will only increase the necessity of recognizing such dynamism in ecosystems. Reference conditions and historic ranges of variability are also concepts that will need to be re-evaluated as management tools because the trajectories of forest ecosystems will be away from conditions we are familiar with and future disturbance regimes will likely exceed 
the range of historic variability. All this does not mean that there is no utility in planning - quite the opposite. It means planning for expected conditions and what they mean for resource management - it may well mean changing the mandates and goals of land management agencies to reflect new conditions and priorities. It may also mean planning for unexpected conditions, and experimenting with novel ideas (or reviving old ideas) particularly when there is too much uncertainty in projections. It quite likely also means using available tools now (silviculture, crossagency collaboration) while considering the barriers to using other tools (e.g., prescribed fire). In order to accomplish this, however, a concerted effort to increase communication between scientists, managers, and policy makers is required - the rates of change expected and the nature of the impacts will require broad collaboration.

\section{Research Needs}

\subsection{Finer-Scale Climatic Projections in Mountain and Forest Ecosystems}

Climate in the complex terrain associated with forest ecosystems is poorly understood. Much more needs to be known about how to downscale regional climate to local conditions and whether such downscaling will decrease the uncertainty forest managers face. In particular, will there be substantial differences in the way climate will change in different geographic areas (e.g., for maritime vs. continental) or different elevational zones. Current data resources and future scenarios are generally inadequate to assess impacts at scales useful for managers.

\subsection{Understand the Geographic Distribution of Genetic Variability and Climatic Tolerances for Tree Species}

Planning for future resilience and responses to disturbance require well developed knowledge of genotypic variability and sub-species climatic tolerances so that seed stock well adapted to likely future conditions can be selected. The geographic variability of sub-species genotypes and how those genotypes perform in different climatic conditions is poorly documented for most species. Some climatic changes could have substantial differences in their impacts on different species within the same stand due to differences in physiology, life history, morphology, etc., and the implications of these need to be better understood in the context of energy and water limitation.

\subsection{Understand the Role of Climate in Tree Establishment Generally, but Particularly Post-Fire and at Lower Treeline, to Prioritize Post-Disturbance Treatments and Planting Efforts}

The success of tree establishment after disturbance likely varies with climate, but the degree to which climate limits establishment is not well known. Most of the bioclimatic approaches to future vegetation response to climate change do not account for this potential sensitivity in early lifehistory stages and instead focus on climate relationships for established 
trees. Because establishment is more sensitive than persistence of established trees, it is likely that important tree species will fail to establish after disturbance when the climate has shifted sufficiently.

\subsection{Move from Fire Area Burned to Landscape Fire Effects and Fire Severity}

The area burned by fire is not the best metric of ecological impact - the role of future fire in forested landscapes depends as much or more on fire effects and fire severity as on the area burned. Physically based models at finer spatial scales are needed to address impacts of changing fire regimes on vegetation and watershed hydrology. Fire also has important implications for short-term hydrologic response after disturbance, which may include important feedbacks to biological effects in forest and aquatic systems.

\subsection{Understand How Other Insects (e.g., Spruce and Fir Beetles) and Pathogens Respond to Climatic Change.}

The mountain pine beetle is not the only insect species that may have greater impacts in a warming climate, and the role of climate in other insects' life cycles and host vulnerabilities must be better understood if we are to anticipate future impacts.

\subsection{More Research on the Impacts and Benefits of Silvicultural Treatments on Fire Behavior and Stand Vigor is Needed}

Forest managers need tools for climate change adaptation, and a tool that is available now is silviculture. Appropriate silvicultural prescriptions require knowledge of expected local impacts and stand and tree physiological thresholds that may not have historical analogues. The potential impacts identified in this paper point to two silvicultural research needs. First we must better understand the physiological response of mature trees to changing climate conditions to determine if silvicultural treatments could stem those impacts. Second we need to understand how different silvicultural treatments can be used in anticipation of different projected climatic changes. The impacts and benefits of silvicultural treatments on forest ecosystems processes such as fire severity are generally poorly quantified.

\section{Conclusions}

- Spatial patterns of productivity will change -- state-wide productivity may initially increase due to warmer temepratures but will then decrease due to increased drought stress. Douglas-fir productivity appears to vary with climate across the region and will potentially increase in energy-limited forests in the near term. Climatic variability will continue to mediate productivity.

- Species composition will be affected by climate, and the consequences for lower elevation forests and for species susceptible to mountain pine beetle are potentially substantial. Climate will be 
inconsistent with the establishment of Douglas-fir, ponderosa pine, and lodgepole pine in many areas by the middle of the $21^{\text {st }}$ century. Forest species composition will likely change chiefly in the wake of large disturbances and may be affected by climatic limitation of regenerating trees.

- Regional fire area burned may increase two- or three-fold. Fire regimes in different ecosystems in the PNW have different sensitivities to climate. Year-to-year variation will continue and potentially increase, and will also be a challenge for planning.

Due to climatic stress on host trees, mountain pine beetle outbreaks may increase in frequency and levels of tree mortality. Mountain pine beetles will reach higher elevations due to a shift in favorable temperature conditions in these areas as the region warms. Conversely, this species may become less of a threat at middle and lower elevations as the region warms, due to less favorable temperature conditions. Other insect species may emerge in areas that are no longer suitable for the mountain pine beetle.

\section{Acknowledgments}

Alan Hamlet, Richard Gwozdz, and Ingrid Tohver provided detailed comments on an earlier draft of the manuscript. We thank three anonymous reviewers for helpful suggestions. We would also like to thank G. Rehfeldt and N. Crookton for making their output for future species ranges publicly available.

\section{References}

Agee, JK, Flewelling R (1983) A fire cycle model based on climate for the Olympic Mountains, Washington. Proc Fire For Met Conf 7:32-37.

Akaike, H (1974) A new look at the statistical model identification. IEEE Trans Auto Control 19(6): 716-723.

Allen, CD, Breshears DD (1998) Drought-induced shift of a forest-woodland ecotone: Rapid landscape response to climate variation. Proc Natl Acad Sci USA 95:14839-14842.

Bailey RG (1995) Description of the ecoregions of the United States. USDA For Service Miscs Public 1391 (revis) Washington, DC.

Bentz BJ, Logan JA, Amman GD (1991) Temperature-dependent development of mountain pine beetle and simulation of its phenology. Can Entomol 123:1083-1094.

Boisvenue C, Running SW (2006) Impacts of climate change on natural forest productivity - evidence since the middle of the 20th century. Global Biogeochem Cycles 12:862-882.

Breshears DD, Cobb NS, Rich PM, Price KP, Allen CD, Balice RG, Romme WH, Kastens JH, Floyd ML, Belnap J, Anderson JJ, Myers OB, Meyer CW (2005) Regional vegetation die-off in response to global-change type drought. Proc Nat Acad Sci, USA 102:15144-15148.

Carroll AL, Taylor SW, Regniere J, Safranyik L (2004) Effects of climate change on range expansion by the mountain pine beetle in British Columbia. In: Mountain Pine Beetle Symposium: Challenges and Solutions. Nat Resour Can, Can For Serv, Pacific For Cent, Kelowna, BC, pp 223-232.

Case MJ, Peterson DL (2007) Growth-climate relations of lodgepole pine in the North Cascades National Park, Washington. Northwest Sci 81(1):62-75. 
Cayan DR (1996) Interannual climate variability and snow pack in the western United States. J Climate 9(5):928-948.

Daly C, Halbleib M, Smith JI, Gibson WP, Doggett MK, Taylor GH, Curtis J, Pasteris PA (2008) Physiographically sensitive mapping of temperature and precipitation across the conterminous United States. Int J Climatol DOI: 10.1002/joc.1688.

Davis MB (1986) Climatic instability, time lags, and community disequilibrium. In: Diamond J, Case TJ, eds. Community Ecology. P. 269-284. Harper and Row. New York.

Davis MB, Botkin DB (1985) Sensitivity of cool-temperate forests and their fossil pollen record to rapid temperature change. Quaternary Res 23:327-340.

DeLucia EH, Maherali H, Carey EV (2000) Climate-driven changes in biomass allocation in pines. Global Change Biol 6(5):587-593.

Cushman SA, McKenzie D, Peterson DL, Littell JS, McKelvey KS (2007) Research agenda for integrated landscape modeling. USDA For Serv Gen Tech Rep RMRSGTR-194. Rocky Mt Res Stn, Fort Collins, CO.

Elsner MM, Cuo L, Voisin N, Hamlet AF, Deems JS, Lettenmaier DP, Mickelson KEB, Lee SY (2009) Implications of climate change for the hydrology of Washintgon State. Washington Climate Change Impacts Assessment: Evaluating Washington's future in a changing climate. In press.

Franklin JF, Dyrness CT (1988) Natural vegetation of Oregon and Washington. Oregon State Univerity Press, Corvallis, OR.

Gedalof Z, Peterson DL, Mantua NJ (2005) Atmospheric, climatic, and ecological controls on extreme wildfire years in the Northwestern United States. Ecol Appl 15:154174 .

Gillett NP, Weaver AJ, Zwiers FW, Flannigan MD (2004) Detecting the effect of climate change on Canadian forest fires. Geophys Res Lett 31, L18211, doi:10.1029/2004GL020876.

Guisan A, Zimmermann NE (2000) Predictive habitat distribution models in ecology. Ecol Modell 135:147-186.

Henderson JA, Peter DH (1981) Preliminary plant associations and habitat types of the Shelton Ranger District, Olympic National Forest. USDA For Serv, Pacific Northwest Reg, Portland, OR 53 p.

Henderson JA, Peter DH, Lesher RD, Shaw DC (1989) Forested plant associations of the Olympic National Forest. USDA For Service, Pacific Northwest Res Stn R6-ECOL-TP-001-88, Portland, OR 502 p.

Henderson JA, Lesher RD, Peter DH, Shaw DC (1992) Field guide to the forested plant associations of the Mt. Baker-Snoqualmie National Forest. USDA For Service, Pacific Northwest Res Stn R6-ECOL-TP-028-91, Portland, OR.

Hessl AE, McKenzie D, Schellhaas R (2004) Drought and Pacific Decadal Oscillation affect fire occurrence in the inland Pacific Northwest. Ecol Appl 14:425-442.

Hicke, JA, Jenkins JC (2008) Mapping lodgepole pine stand structure susceptibility to mountain pine beetle attack across the western United States. For Ecol Manage 255:1536-1547.

Hicke JA, Logan JA, Powell J, Ojima DS (2006) Changing temperatures influence suitability for modeled mountain pine beetle (Dendroctonus ponderosae) outbreaks in the western United States, J Geophys Res B, 111, G02019, doi: 10.1029/2005JG000101.

IPCC (Intergovernmental Panel on Climate Change) (2007) Climate Change 2007: the Physical Science Basis. Summary for policymakers. http://www.ipcc.ch

IPCC (Intergovernmental Panel on Climate Change) (2007) Working Group II Report "Impacts, Adaptation and Vulnerability". http://www.ipcc.ch/ipccreports/ ar4-wg2.htm 
Jenkins MJ, Hebertson E, Page W, Jorgensen CA (2008) Bark beetles, fuels, fires and implications for forest management in the Intermountain West. For Ecol Manage 254(1):16.

Joyce LA, Blate GM, Littell JS, McNulty SG, Millar CI, Moser SC, Neilson RP (2008) National forests. Chapter 3 In: S.H. Julius, J.M. West (eds.), J.S. Baron, B.Griffith, L.A. Joyce, P. Kareiva, B.D. Keller, M.A. Palmer, C.H. Peterson, and J.M. Scott (authors), Preliminary Review of Adaptation Options for Climate-Sensitive Ecosystems and Resources. A report by the U.S. Climate Change Science Program and the Subcommittee on Global Change Research. U.S. Environmental Protection Agency, Washington, DC, USA, pp. 3-1 to 3-127.

Kimball JS, Running SW, Nemani R (1997) An improved method for estimating surface humidity from daily minimum temperature. Agric For Meteorol 85:87-98.

Knowles N, Dettinger MD, Cayan DR. 2006. Trends in snowfall versus rainfall in the western United States. J Climate 19:4545-4559.

Lenihan JM, Bachelet D, Neilson RP, Drapek RJ (2008) Simulated response of conterminous united states ecosystems to climate change at different levels of fire suppression, $\mathrm{CO} 2$ emission rate, and growth response to $\mathrm{CO} 2$. Global Planetary Change 64:16-25.

Lillybridge TR, Kovalchik BL, Williams CK, Smith BG (1995) Field guide to forested plant associations of the Wenatchee National Forest. USDA For Serv Gen Tech Rep PNW-GTR-359. Pacific Northwest Res Stn, Portland, OR, USA, 336 p.

Littell JS (2006) Climate Impacts to Forest Ecosystem Processes: Douglas-fir Growth in Northwestern U.S. Mountain Landscapes and Area Burned by Wildfire in Western U.S. Ecoprovinces. Ph.D. dissertation. University of Washington, Coll For Resources, Seattle, Washington, USA. 160 p.

Littell JS, Peterson DL (2005) A method for estimating vulnerability of Douglas-fir growth to climate change in the Northwestern US. Forestry Chron 81:369-374.

Littell JS, Peterson DL, Tjoelker M (2008) Douglas-fir growth-climate relationships along biophysical gradients in mountain protected areas of the northwestern U.S. Ecol Monogr 78(3): 349-368.

Littell JS, McKenzie D, Peterson DL, Westerling AL (2009) Climate and wildfire area burned in western U.S. ecoprovinces, 1916-2003. Ecol Appl (in press).

Logan JA, Bentz BJ (1999) Model analysis of mountain pine beetle (Coleoptera: Scolytidae) seasonality. Env Entomol 28:924-934.

Logan JA, Amman GD (1986) A distribution model for egg development in mountain pine beetle. Can Entomol 118:361-372.

Logan JA, Bolstad PV, Bentz BJ, Perkins DL (1995) Assessing the effects of changing climate on mountain pine beetle dynamics. In: Workshop on Interior West Global Climate. USDA For Serv, Fort Collins, CO pp 92-105.

Logan JA, Powell JA (2001) Ghost forests, global warming and the mountain pine beetle (Coleoptera: Scolytidae). Am Entomol 47:160-173.

Logan JA, Powell JA (2004) Modeling mountain pine beetle phenological response to temperature. In: Mountain Pine Beetle Symposium: Challenges and Solutions. Nat Res Can, Can For Service, Pacific For Cent, Kelowna, BC pp. 210-222

Lloyd AH, Graumlich LJ (1997) A 3,500 year record of changes in the structure and distribution of forests at treeline in the Sierra Nevada, California, U.S.A. Ecology 78:1199-1210.

Lutz JA (2008) Climate, fire, and vegetation change in Yosemite National Park. Ph.D. dissertation. University of Washington, Coll For Resources Seattle, Washington, USA. 169 p.

Lutz JA and Halpern CB (2006) Tree mortality during early forest development: a longterm study of rates, causes, and consequences. Ecol Monogr 76:257-275. 
Lynch HJ, Renkin RA, Crabtree RL, Moorcroft PR (2006) The influence of previous mountain pine beetle (Dendroctonus ponderosae) activity on the 1988 Yellowstone fires. Ecosystems 9:1318-1327.

McKenzie D, Gedalof Z, Peterson DL, Mote PW (2004) Climatic change, wildfire, and conservation. Conserv Biol 18:890-902.

McKenzie D, Hessl AE, Peterson DL (2001) Recent growth in conifer species of western North America: assessing the spatial patterns of radial growth trends. Can J For Res 31:526-538.

McKenzie D, Peterson DL, Littell JS (2008) Global warming and stress complexes in forests of western North America. In S. V. Krupa (ed.), Developments in Environmental Science, Vol. 8, Wild Land Fires and Air Pollution, A. Bytnerowicz, M. Arbaugh, A. Riebau, and C. Anderson (eds.). Amsterdam, The Netherlands: Elsevier Science, Ltd. pp. 319-337.

McKenzie D, Peterson DW, Peterson DL, Thornton PE (2003) Climatic and biophysical controls on conifer species distributions in mountain forests of Washington state, USA. J Biogeogr 30:1093-1108.

Millar CI, Stephenson NL, Stephens SL (2007) Climate change and forests of the future: managing in the face of uncertainty. Ecol Appl 17:2145-2151.

Milne BT, Gupta VK, Restrepo C (2002) A scale-invariant coupling of plants, water, energy, and terrain. EcoScience 9:191-199.

Mote PW, Hamlet AF, Clark MP, and Lettenmaier DP. 2005. Declining mountain snowpack in western North America. Bull Am Meteorol Soc 86:39-49.

Mote PW, Salathé Jr EP (2009) Future climate in the Pacific Northwest. Washington Climate Change Impacts Assessment: Evaluating Washington's future in a changing climate. In press.

Nakawatase JM, Peterson DL (2006) Spatial variability in forest growth-climate relationships in the Olympic Mountains, Washington. Can J For Res 36: 77-91.

Neilson RP, Pitelka LF, Solomon AM, Nathan R, Midgley GF, Fragoso JMV, Lischke H, Thompson K (2005) Forecasting regional to global plant migration in response to climate change. BioScience 55:749-759.

Oneil EE (2006) Developing stand density thresholds to address mountain pine beetle susceptibility in eastern Washington forests. PhD Dissertation, University of Washington, Seattle, 99pp.

Overpeck JT, Rind D, Goldberg R (1990) Climate-induced changes in forest disturbance and vegetation. Nature 343:51-53.

Peterson DW, Peterson DL (2001) Mountain hemlock growth responds to climatic variability at annual and decadal scales. Ecology 82:3330-3345.

Powell JA, Logan JA (2005) Insect seasonality: circle map analysis of temperature-driven life cycles. Theor Pop Biol 67:161-179.

Rehfeldt GE, Crookston NL, Warwell MV, Evans JS (2006) Empirical analysis of plant-climate relationships for the western United States. Int J Plant Sci 167(6):1123-1150.

Running SW, Nemani RR, Heinsch FA, Zhao M, Reeves M, Hashimoto H (2004) A continuous satellite-derived measure of global terrestrial primary production. BioScience 54(6):547-560.

Running SW, Nemani RR, et al (1987) Extrapolation of synoptic meteorological data in mountainous terrain and its use for simulating forest evapotranspiration and photosynthesis.” Can J For Res 17(6): 472-483.

Salathé Jr EP, Mote PW, Wiley MW (2007) Review of scenario selection and downscaling methods for the assessment of climate change impacts on hydrology in the United States Pacific Northwest. Int J Climatol 27:1611-1621. 
Stephenson NL (1990) Climatic control of vegetation distribution: the role of the water balance. Am Nat 135:649-670.

Stephenson NL (1998) Actual evapotranspiration and deficit: biologically meaningful correlates of vegetation distribution across spatial scales. J Biogeogr 25, 855-870.

Thornton PE, Hasenauer H, White MA (2000) Simultaneous estimation of daily solar radiation and humidity from observed temperature and precipitation: an application over complex terrain in Austria. Agric For Meteorol 104:255-271.

Thornton PE, Running SW (1999). An improved algorithm for estimating incident daily solar radiation from measurements of temperature, humidity, and precipitation. Agric For Meteorol 93(4): 211-228

Thornton PE, Running SW, et al (1997). Generating surfaces of daily meteorological variables over large regions of complex terrain. J Hydrol 190(3-4): 214-251.

van Mantgem PJ, Stephenson NL (2007) Apparent climatically induced increase of tree mortality rates in a temperate forest. Ecol Lett 10:909-916.

van Mantgem PJ, Stephenson NL, Byrne JC, Daniels LD, Franklin JF, Fulé PZ, Harmon ME, Larson AJ, Smith JM, Taylor AH, Veblen TT (2009) Widespread increase of tree mortality rates in the western United States. Science Vol. 323: 521 - 524 DOI: $10.1126 /$ science. 1165000

Venables WN, Ripley BD (2002) Modern Applied Statistics with S. 4th edition. Springer, New York. 495 pp.

Waring RH, Running SW (1998) Forest Ecosystems: Analysis at Multiple Scales. Academic Press, New York. 370 pp.

Wellner CA (1978) Management Problems Resulting from Mountain Pine Beetles in Lodgepole Pine Forests, pp 9-15 in Theory and Practice of Mountain Pine Beetle Management in Lodgepole Pine Forests, Pullman, WA, For, Wildlife and Range Exp Stn, University of Idaho.

Williams CK, Lillybridge TR (1983) Forested plant associations of the Okanogan National Forest. USDA Forest Serv Tech Pap R6-ECOL-132b-1983. Pacific Northwest Res Stn, Portland, OR, USA, p. 140.

Williams CK, Lillybridge TR, Smith BG (1990) Forested plant associations of the Colville National Forest, field guide. USDA Forest Service, Pacific Northwest Res Stn, Portland, OR, USA, p. 133.

Photo credit, page 263: Climate Impacts Group, University of Washington 